\title{
Carbon export fluxes in the Southern Ocean: results from inverse modeling and comparison with satellite-based estimates
}

\author{
Reiner Schlitzer
}

Alfred-Wegener-Institute for Polar and Marine Research, Postfach 120161, 27515 Bremerhaven, Germany

\begin{abstract}
The use of dissolved nutrients and carbon for photosynthesis in the euphotic zone and the subsequent downward transport of particulate and dissolved organic material strongly affect carbon concentrations in surface water and thus the air-sea exchange of $\mathrm{CO}_{2}$. Efforts to quantify the downward carbon flux for the whole ocean or on basin-scales are hampered by the sparseness of direct productivity or flux measurements. Here, a global ocean circulation, biogeochemical model is used to determine rates of export production and vertical carbon fluxes in the Southern Ocean. The model exploits the existing large sets of hydrographic, oxygen, nutrient and carbon data that contain information on the underlying biogeochemical processes. The model is fitted to the data by systematically varying circulation, air-sea fluxes, production, and remineralization rates simultaneously. Use of the adjoint method yields model property simulations that are in very good agreement with measurements.

In the model, the total integrated export flux of particulate organic matter necessary for the realistic reproduction of nutrient data is significantly larger than export estimates derived from primary productivity maps. Of the $10,000 \mathrm{TgC} \mathrm{yr}^{-1}\left(10 \mathrm{GtC} \mathrm{yr}^{-1}\right)$ required globally, the Southern Ocean south of $30^{\circ} \mathrm{S}$ contributes about $3000 \mathrm{TgC} \mathrm{yr}^{-1}(33 \%)$, most of it occurring in a zonal belt along the Antarctic Circumpolar Current and in the Peru, Chile and Namibia coastal upwelling regions. The export flux of POC for the area south of $50^{\circ} \mathrm{S}$ amounts to

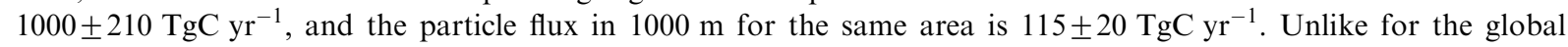
ocean, the contribution of the downward flux of dissolved organic carbon is significant in the Southern Ocean in the top $500 \mathrm{~m}$ of the water column. Comparison with satellite-based productivity estimates (CZCS and SeaWiFS) shows a relatively good agreement over most of the ocean except for the Southern Ocean south of $50^{\circ} \mathrm{S}$, where the model fluxes are systematically higher than the satellite-based values by factors between 2 and 5 . This discrepancy is significant, and an attempt to reconcile the low satellite-derived productivity values with ocean-interior nutrient budgets failed. Too low productivity estimates from satellite chlorophyll observations in the polar and sub-polar Southern Ocean could arise because of the inability of the satellite sensors to detect frequently occurring sub-surface chlorophyll patches, and to a poor calibration of the conversion algorithms in the Southern Ocean because of the very limited amount of direct measurements. (C) 2002 Elsevier Science Ltd. All rights reserved.
\end{abstract}

\section{Introduction}

A number of recent observational and modeling studies have emphasized the important role of the

\footnotetext{
E-mail address: rschlitzer@awi-bremerhaven.de (R. Schlitzer).
}

Southern Ocean in the global carbon cycle and for the uptake of anthropogenic $\mathrm{CO}_{2}$ by the ocean. Using a huge, global dataset of $p \mathrm{CO}_{2}$ measurements, Takahashi et al. (1999) find large sinks for atmospheric $\mathrm{CO}_{2}$ in the Southern Ocean, and they suggest that more than half of the global ocean $\mathrm{CO}_{2}$ uptake could be occurring there. Model

0967-0645/02/\$ - see front matter (C) 2002 Elsevier Science Ltd. All rights reserved.

PII: S 0967 - 0645 ( 02 ) 00004 - 8 
results of Sarmiento et al. (1998, 2000), and Caldeira and Duffy (2000) also show high fluxes of anthropogenic carbon dioxide into the Southern Ocean as a result of physical and biological processes. These models suggest that climatic changes and a global warming trend have strongest effects in the Southern Ocean and could substantially affect the ocean carbon sink over the next few decades.

The Southern Ocean is one of the few oceanic regions where the supply of the major nutrients phosphate, nitrate, silicate, and carbon to the surface layer due to strong and deep-reaching upwelling of nutrient-rich waters (Toggweiler, 1994) is large and obviously exceeds the local demand required by biological activity in that area. Observations of surface-water chlorophyll levels, either by shipboard or satellite-based measurements, reveal significantly lower concentrations than those found in coastal upwelling areas. This has been interpreted as a sign of only moderately high productivity. The large supply together with moderate nutrient uptake leads to high nutrient and carbon concentrations in Southern Ocean surface waters and to a net equatorward nutrient transport in the upper layers. The Southern Ocean south of the sub-tropical front (about $40^{\circ} \mathrm{S}$; Orsi et al., 1995) is therefore referred to as a high nutrient-low chlorophyll (HNLC) region. The questions of why marine ecosystems are unable to make more efficient use of the available nutrients and what limits biological productivity in the Southern Ocean are still under discussion. Possible explanations range from physical effects including strong vertical mixing and weak vertical stratification to grazing pressure (Frost, 1991) and the unavailability of other micronutrients, such as iron (de Baar et al., 1995; Behrenfeld and Kolber, 1999).

With respect to carbon, the biological activity in the surface layer that causes a drawdown of dissolved nutrient concentrations and results in sinking particulate matter is an essential process, because it lowers the partial pressure of $\mathrm{CO}_{2}$ in the surface water and thus affects the $\mathrm{CO}_{2}$ gasexchange with the atmosphere. Depending on the magnitude of the biological production, an area that otherwise would outgas $\mathrm{CO}_{2}$ to the atmosphere because of the high carbon concentrations in the upwelled water can turn into a net sink of atmospheric $\mathrm{CO}_{2}$ if the "pumping" effect of the downward particle flux is sufficiently large. Thus, in areas like the Southern Ocean, the net air-sea flux of $\mathrm{CO}_{2}$ is the result of a delicate balance between the supply of carbon from below (favoring outgasing to the atmosphere) and the drawdown of surface nutrients and carbon by biological activity (favoring uptake from the atmosphere). An assessment of the role of the Southern Ocean in the global carbon cycle therefore requires a reliable determination of both the upward flux of nutrients into the euphotic zone by physical processes and of the downward particulate and dissolved organic nutrient and carbon export due to biological productivity.

Quantifying physical and biogeochemical nutrient and carbon fluxes is addressed in the present paper by means of a global circulation, biogeochemical model that uses large, global datasets for the hydrographic parameters, dissolved nutrients, oxygen and carbon. Embedded in the distributions of these parameters are structures such as subsurface oxygen minima or nutrient maxima that are the long-term results of biogeochemical processes and large-scale circulation. By applying state-of-the-art optimization techniques, the present model is fitted to available concentrations, and the optimal export production, particle remineralization and circulation are calculated. The overall objective is that the model-derived biogeochemical and physical fluxes explain the observed hydrographic, nutrient, oxygen and carbon fields in a realistic way and are thus consistent with observations.

This modeling approach is very different from the method of deriving marine productivity fields on the basis of surface-ocean chlorophyll measurements from satellite sensors (Longhurst et al., 1995; Antoine et al., 1996; Behrenfeld and Falkowski, 1997; Arrigo et al., 1998). In the case of the satellite-based productivity fields, the system is viewed from above and the chlorophyll fields exhibit the large temporal and spatial variability inherent in biological productivity dynamics, whereas in the case of the present model the system is viewed from below the euphotic zone and 
structures in the property fields for the whole water column caused by the biogeochemical processes are exploited. Comparisons of measurements from re-occupied stations show that nutrient and oxygen profiles change little even on time-scales of several decades. Thus, the signatures in the nutrient fields represent the long-term net effect of biogeochemical processes and are largely unaffected by spatial or temporal extremes.

Another important difference between the two approaches is that the satellite sensors can detect only the chlorophyll signal in the top 10-20 m of the water column. There is no information on biological activity from deeper parts of the euphotic zone, nor is there any information on the subsequent remineralization of particulate matter below the euphotic zone. On the other hand, the distributions of dissolved nutrients and oxygen capture both the production in the upper layers and the remineralization of the sinking material in the water column and at the sedimentwater interface.

In this paper, the results of the global model for the Southern Ocean are presented in detail. These include the spatial pattern of export production of particulate organic carbon (POC), the remineralization rates and changes of the POC flux with depth, and the distribution as well as the vertical flux of dissolved organic carbon (DOC). The model-derived field of export production is then compared with productivity estimates from satellite chlorophyll or pigment observations, which reveals significant and systematic differences in the Southern Ocean. Possible causes for these discrepancies are discussed.

\section{Data}

This study exploits the historical data archives for temperature, salinity, oxygen, phosphate, nitrate, silicate, dissolved inorganic carbon (DIC) and total alkalinity for the world ocean. Before using, however, these data have been quality controlled carefully by means of the Ocean Data View system (Schlitzer, 2000c). Rather than resorting to gridded datasets of the property distributions as done in other modeling efforts, the data are used in their original form and any averaging is done in the context of the present model (see Section 3.2). There are two advantages in this approach: (1) the averaging procedure and the degree of retained spatial resolution are controlled by the individual researcher and determined by grid resolution; (2) information on range and variability of the original measurements in a given grid-cell can be used to derive error information for the data, which is essential for the model but usually not provided with gridded datasets.

The global, quality controlled dataset consists of more than 40,000 stations that span the last 80 years, most since 1950, with strong contributions from the 1960s and the 1990s. The high-quality data from the World Ocean Circulation Experiment (WOCE) included in this dataset are available at http://www.awi-bremerhaven.de/GEO/ eWOCE (Schlitzer, 2000b). About $47 \%$ of the stations lie in the southern hemisphere and about $30 \%$ south of $30^{\circ} \mathrm{S}$. Nearly all of the stations contain top-to-bottom data for temperature and salinity. About $75 \%$ of the stations contain oxygen data, $63 \%$ have phosphate, $59 \%$ silicate, $53 \%$ nitrate and about 7\% DIC and alkalinity.

With the exception of a few areas along the Antarctic continent and some open-ocean regions in the South Atlantic and Indian Ocean the spatial coverage is good (Fig. 1) and sufficient to capture the large-scale features in the various property fields. Moreover, there are more than a thousand stations for each individual month, with a clear bias towards the southern hemisphere summer season (Fig. 2a). This bias is most pronounced for the polar areas around Antarctica, where very few winter observations exist. There is a large contribution of very recent stations with data of high quality (e.g., WOCE), but the period from 1950 to 1980 also seems to be well represented (Fig. 2b).

Unlike at low, and mid-latitudes, the annual mean phosphate concentrations in Southern Ocean surface waters (Fig. 3) are very high in an area bounded to the north by the sub-tropical front near $40^{\circ} \mathrm{S}$. Phosphate concentrations can reach up to $2 \mu \mathrm{mol} \mathrm{kg}{ }^{-1}$, the highest surface water values in the world ocean. These high nutrient levels are the result of upwelling of nutrient-rich 


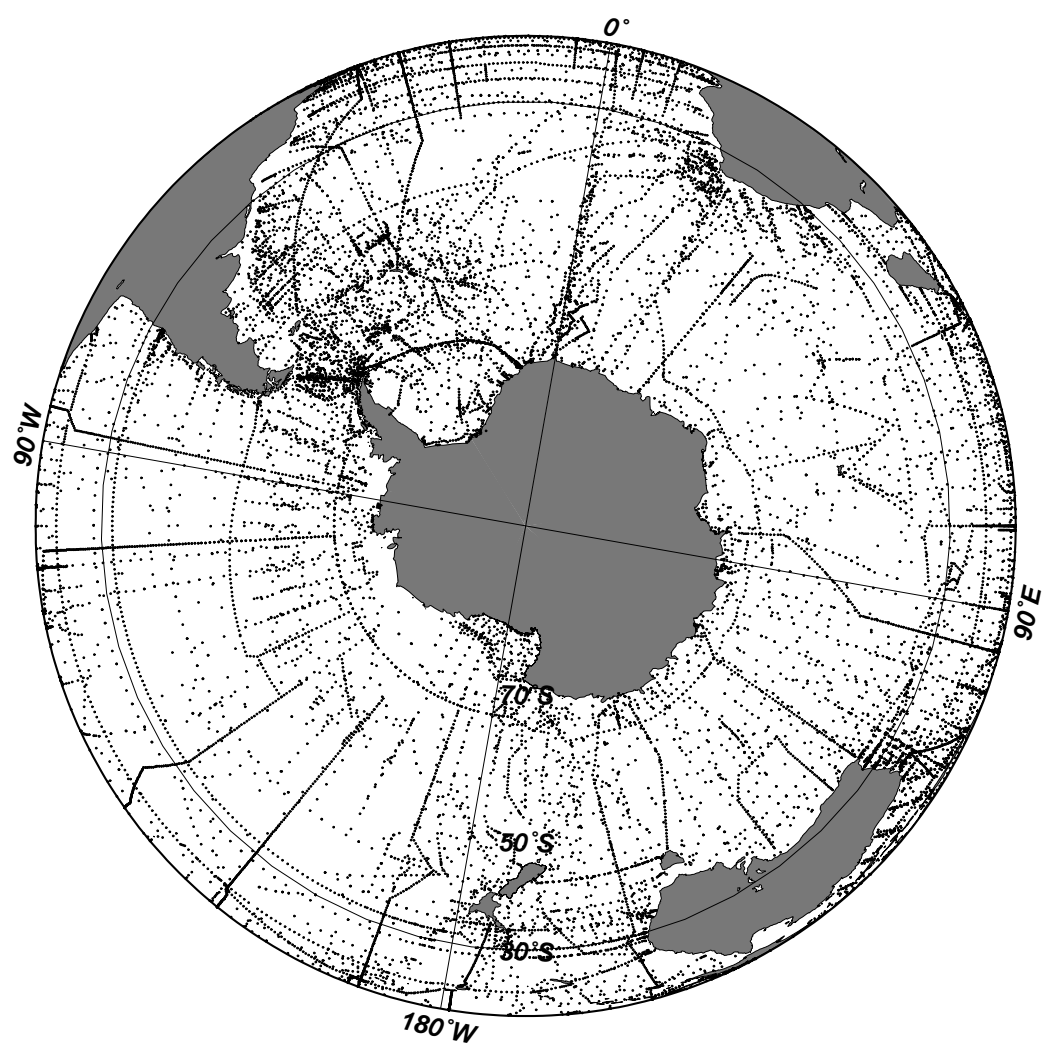

Fig. 1. Location of hydrographic and nutrient stations used in the present study. Note that the global model also uses about the same number of stations in the northern hemisphere.

water that obviously is not fully taken up by biological productivity.

As described by Schlitzer (2000a), the available hydrographic, oxygen, nutrient and carbon measurements reflect the combined effect of circulation and biogeochemical processes. The oxygen, nutrient, and carbon distributions exhibit large and distinct features that can only be explained by biological production in the surface layer and by subsequent remineralization of the sinking material. The well-documented sub-surface oxygen minima and associated nutrient maxima are a clear hint to particle remineralization, and the vertical confinement of these features reveals the depth horizons where the remineralization is occurring, and thus allowing one to determine the decrease of the particle flux with depth. To determine the underlying productivity and remineralization rates, however, requires models that appropriately take into account physical transport as well as biogeochemistry.

\section{The model}

The model is formulated as a constrained optimization and the solution is found iteratively. In contrast to ecosystem models (e.g. Fasham et al., 1990), which describe the complicated interactions and feedbacks of biological food-webs, the present effort does not model explicitly the processes leading to the formation and export of particles or to their subsequent remineralization. Instead, production or remineralization rates are only constrained by the requirement to 

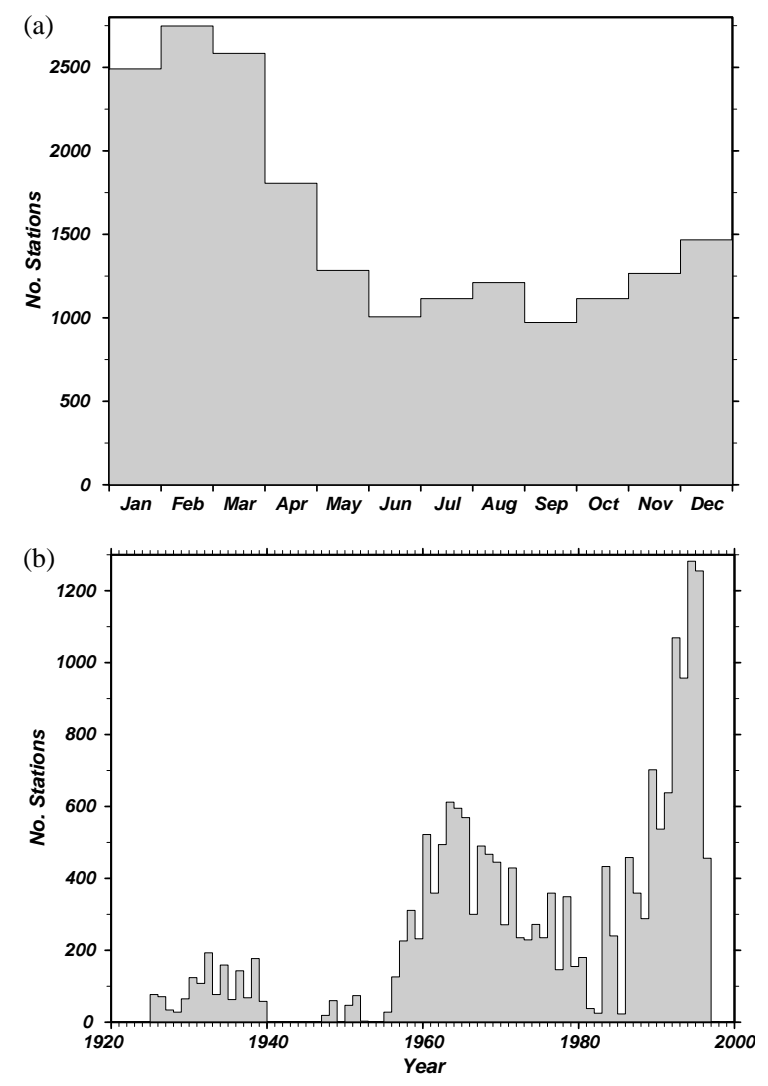

Fig. 2. Temporal distribution of the stations shown in Fig. 1(a) monthly, and (b) between 1920 and 2000.

reproduce the observed property distributions realistically.

As emphasized above, determining particle fluxes and near-surface production rates from nutrient concentrations requires a biogeochemical model that also includes the ocean's 3-D circulation. Here, I use the global model of Heras and Schlitzer (1999), which has been fitted to global hydrographic fields. The general model strategy is based on Schlitzer (1993), and the implementation of biogeochemical processes is as in Schlitzer (2000a). In the following, a description of the essential elements of the biogeochemical model is given. For more details on the adjoint technique applied for the optimization of the model, on the implementation of the geostrophic principle, and for a complete discussion of the various terms in the model's cost function see Schlitzer (2000c).
Overall goal of the model calculations is to find a steady global ocean flow field (representing the climatological mean circulation) and mean export production as well as remineralization fields for three particle classes: (1) particulate organic material (POC), (2) opal, and (3) $\mathrm{CaCO}_{3}$. To be considered optimal, the calculated velocities must have velocity shears close to geostrophic shear estimates, and simulations of hydrographic and nutrient distributions using model flows and biogeochemical parameters must reproduce the respective observations closely (in a least-squares sense). The adjoint method provides the means that drive the model to the desired state.

\subsection{Model grid}

Unlike most other biogeochemical models, the present model has a non-uniform grid with horizontal resolution ranging from $5 \times 4^{\circ}$ longitude by latitude in open ocean areas to $2.5 \times 1^{\circ}$ in regions with narrow currents (Drake Passage, Atlantic part of the Antarctic Circumpolar Current, Indonesian and Caribbean archipelagos), along coastal boundaries with strong currents (Florida Current, Gulf Stream, Brazil Current, Agulhas Current, Kuroshio), over steep topography (Greenland-Iceland-Scotland overflow region), and in areas with pronounced coastal upor down-welling. In all cases, the refinements are implemented in the direction of the strongest property gradients (usually perpendicular to fronts and currents) to trace more accurately changes in ocean properties.

The model has 26 vertical layers, with thicknesses progressively increasing from $60 \mathrm{~m}$ at the surface to approximately 500 at $5000 \mathrm{~m}$ depth. Realistic topography is used based on the US Navy bathymetric data and averaged over gridcells. Model depths over ridges and in narrow channels are adjusted manually to respective sill or channel depths. The model has three open boundaries, along which ocean properties and transports are prescribed in each model layer. They are located at the exits of the Mediterranean Sea, Red Sea, and Persian Gulf. These three marginal seas are not modeled explicitly, but their 


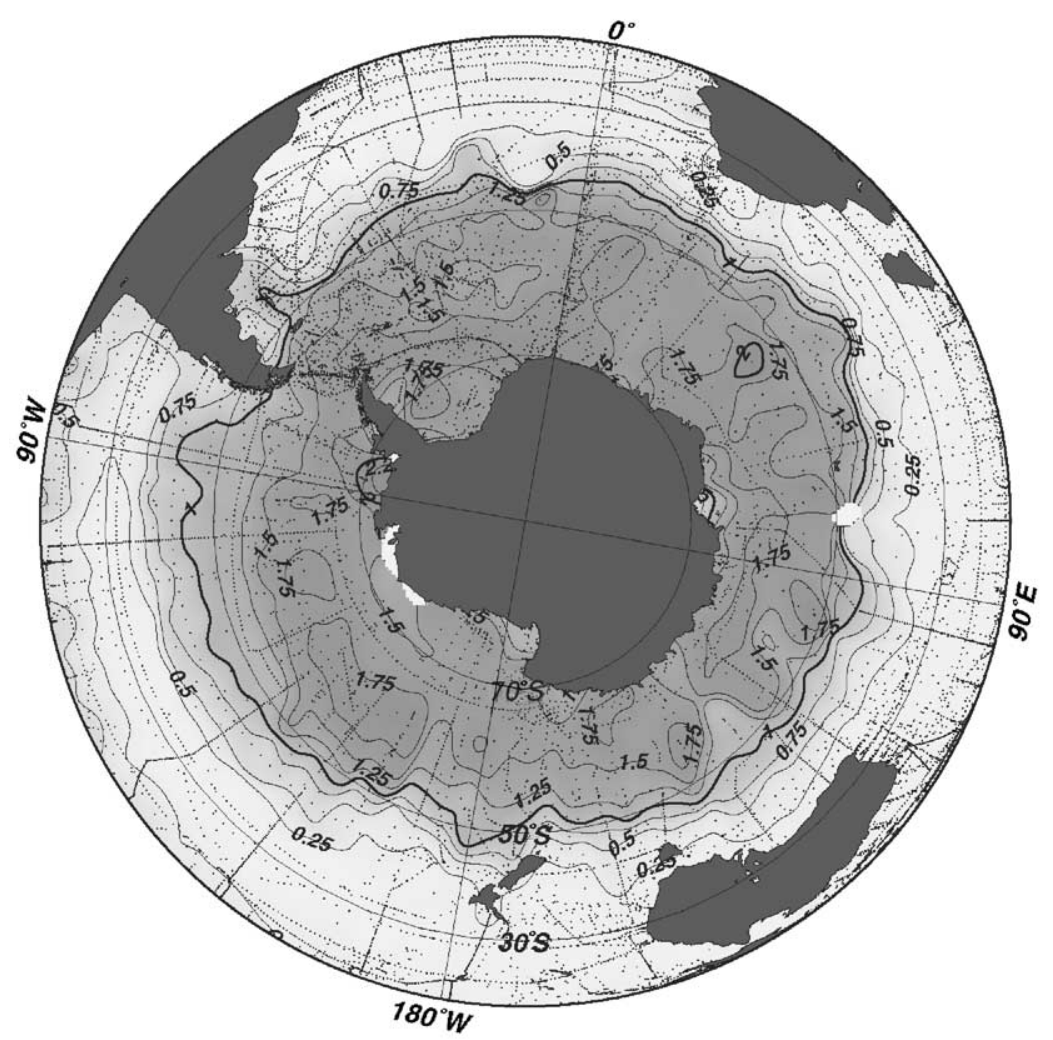

Fig. 3. Distribution of phosphate $\left(\mu \mathrm{mol} \mathrm{kg}{ }^{-1}\right)$ in southern hemisphere surface waters $(10 \mathrm{~m} \mathrm{depth})$. The map is based on data from more than 19,000 stations indicated by small dots.

impact on the global circulation is taken into account.

The model grid described above represents a compromise between the desire to resolve ocean currents and productivity patterns as closely as possible and the large computational burden imposed by the optimization procedure used to drive the model towards the observations (see below). Given present computer resources, this requires a relatively coarse model grid. Using variable resolution in the horizontal allows better representation of smaller scale features at least in some crucial parts of the model domain without the need to accommodate the higher resolution over the entire model domain. Overall, resolution of the present model is much coarser than eddy-resolving dynamical models but is comparable to or better than that used in other models applied for global-ocean biogeochemical and circulation studies (Yamanaka and Tajika, 1996; Maier-Reimer, 1993; Sarmiento and Orr, 1991).

\subsection{Biogeochemical parameters}

Within the model, particulate matter (POC, $\mathrm{CaCO}_{3}$, and opal) is produced in the top two layers, with the top layer contributing $75 \%$ and the second layer contributing $25 \%$ of the total production. The bottom of the second model layer is considered the base of the euphotic zone (here: $z_{\mathrm{EZ}}=133 \mathrm{~m}$ ). Particle fluxes below the euphotic zone are assumed to decrease with depth according to

$j_{P}(z)=a\left(z / z_{\mathrm{EZ}}\right)^{-b}$, 
where $a$ is the particle flux at the base of the euphotic zone, $z_{\mathrm{EZ}}$, and represents the export production. The parameter $b$ determines the shape of particle flux profile and thus controls the depth of remineralization. Large values for $b$ correspond to steep particle flux decreases and thus large remineralization rates just below the euphotic zone, whereas $b$ values close to zero indicate almost constant particle fluxes with depth, with little remineralization in the water column and most of the particle export reaching the ocean floor. This functional relationship is commonly used for organic material (Suess, 1980; Martin et al., 1987; Bishop, 1989); here it is also applied for opal and $\mathrm{CaCO}_{3}$.

In the model, export production $a$ and remineralization scale height $b$ may vary from grid column to grid column and independent parameter sets are used for each of the particle classes. Note that the productivity and remineralization parameters $a$ and $b$ are not parameterized using, for instance, nutrient availability, light intensity or density stratification as in other studies (Yamanaka and Tajika, 1996; Maier-Reimer, 1993), but can be freely chosen by the model to achieve optimality (to be defined below).

For all except one of the numerical experiments described in this paper, the production and decay of semi-labile DOC are taken into account (Kirchman et al., 1991; Hansell and Carlson, 1998). In contrast to the particulate matter, which sinks vertically, DOC follows the water circulation, and during its lifetime it can be advected far away from its production site. Because of lack of a sufficient data, no attempt is made to determine the production and decay rates of the DOC directly from concentration measurements. Instead, the production and subsequent decay of DOC was modeled by including source and sink terms in the carbon, phosphate, nitrate and oxygen budget equations. DOC production was set to be proportional to the export flux of POC using a partition factor $r_{\mathrm{D} / \mathrm{P}}$ between dissolved and particulate components. The remineralization of DOC was assumed to be exponential with a mean lifetime $\tau_{\mathrm{D}}$. Optimal numerical values for the partition factor $r_{\mathrm{D} / \mathrm{P}}$ and the lifetime $\tau_{\mathrm{D}}$ of DOC were selected after several trial-and-error DOC simulations using different values for $r_{\mathrm{D} / \mathrm{P}}$ and $\tau_{\mathrm{D}}$. The $\mathrm{C}: \mathrm{N}: \mathrm{P}: \mathrm{O}$ ratios of DOC are constant over the whole model domain and set equal to the element ratios of POC (see Table 1).

In order to achieve average surface water DOC concentrations of about $40 \mu \mathrm{mol} \mathrm{kg}{ }^{-1}$ and only weak horizontal gradients (Sharp, 1997; Carlson et al., 1994; Martin and Fitzwater, 1992; Kirchman et al., 1991), values of $r_{\mathrm{D} / \mathrm{P}}=1$ and $\tau_{\mathrm{D}}=$ $2 \mathrm{yrs}$ had to be selected. Other values for $r_{\mathrm{D} / \mathrm{P}}$ would result in lower or larger average concentrations, and smaller lifetimes would result in too

Table 1

List of model experiments used in the present study

\begin{tabular}{llll}
\hline Experiment & $\begin{array}{l}\text { Redfield Ratios } \\
\text { P:N:C:O }\end{array}$ & $\begin{array}{l}\text { Dissolved } \\
\text { organic matter }\end{array}$ & $\begin{array}{l}\text { Nitrification/ } \\
\text { denitrification }\end{array}$ \\
\hline A & $1: 16: 106:-138^{\mathrm{a}}$ & No & No \\
$\mathrm{B}$ & $1: 16: 106:-175^{\mathrm{b}}$ & Semi-labile & No \\
$\mathrm{C}$ & $1: 16: 106:-175$ & Semi-labile & $166 \mathrm{Tg} \mathrm{N} \mathrm{yr}^{-1 \mathrm{c}}$ \\
$\mathrm{D}$ & $1: 16: 106:-175$ & Semi-labile & $74 \mathrm{Tg} \mathrm{N} \mathrm{yr}^{-1 \mathrm{~d}}$ \\
$\mathrm{E}^{\mathrm{e}}$ & $1: 16: 106:-175$ & Semi-labile & $166 \mathrm{Tg} \mathrm{N} \mathrm{yr}^{-1}$ \\
$\mathrm{~F}^{\mathrm{f}}$ & $1: 16: 106:-175$ & Semi-labile & $166 \mathrm{Tg} \mathrm{N}^{-1}$ \\
$\mathrm{G}^{\mathrm{g}}$ & $1: 16: 106:-138$ & Semi-labile & $166 \mathrm{Tg} \mathrm{Ny}^{-1}$ \\
\hline
\end{tabular}

\footnotetext{
${ }^{\text {a }}$ Redfield et al. (1963).

${ }^{\mathrm{b}}$ Takahashi et al. (1985); Anderson and Sarmiento (1994).

${ }^{\mathrm{c}}$ Gruber and Sarmiento (1997).

${ }^{\mathrm{d}}$ Codispoti and Christensen (1985).

${ }^{\mathrm{e}}$ Based on C, but enforces Antoine et al. (1996) productivity field.

${ }^{\mathrm{f}}$ Based on E, but no productivity constraints applied.

${ }^{\mathrm{g}}$ Based on C, but additional fit to global chlorofluorocarbon (CFC) and natural carbon-14 data (WOCE DPC, 2000).
} 
large concentration differences between productive, coastal areas and the open ocean, which are not supported by measurements. Yamanaka and Tajika (1996) use a significantly shorter DOC lifetime, but recent evidence suggests that the longer lifetimes may be more appropriate (Anderson and le B. Williams, 1999).

In addition to DOC, the effects of nitrification and denitrification are taken into account for most model experiments. Again, because of the lack of data, nitrogen fixation and denitrification rates are not derived directly from measurements but are specified using information on globally integrated fixation rates from the literature (Gruber and Sarmiento, 1997; Codispoti and Christensen, 1985). In the model, the nitrogen fixation is evenly distributed over those surface areas where dissolved nitrate is lower than $5 \mu \mathrm{mol} \mathrm{kg}{ }^{-1}$, which includes most of the low and mid-latitudes. Denitrification exactly matches total nitrogen fixation and is equally divided into water-column and benthic denitrification. The benthic denitrification was set to be proportional to the POC flux to the sea floor, and the water-column denitrification was evenly spread over all volumes where dissolved oxygen is below $20 \mu \mathrm{mol} \mathrm{kg}{ }^{-1}$. This places most of the denitrification in the Pacific and Indian Ocean between 100 and $800 \mathrm{~m}$ depth, in agreement with observational evidence (Codispoti and Christensen, 1985; Codispoti et al., 1986; Howell et al., 1997).

\subsection{Model strategy}

The entire set of control variables ultimately to be determined by the model includes the three sets of production respective remineralization parameters for POC, opal and $\mathrm{CaCO}_{3}, a$ and $b$ according to (1), air-sea gas exchange fluxes for $\mathrm{CO}_{2}$ and oxygen, $Q_{\mathrm{C}}$ and $Q_{\mathrm{O}}$, air-sea heat fluxes $Q_{\mathrm{H}}$, horizontal and vertical mixing parameters, $p_{k \mathrm{~h}}$ and $p_{k \mathrm{v}}$, as well as horizontal flow velocities $u$ and $v$ for all model levels. This results in a total of 102,306 adjustable parameters, of which about $80 \%$ are velocity parameters $u$ and $v$ and $20 \%$ biogeochemical and air-sea flux parameters.

Steady-state conservation equations for mass, heat, salt, phosphate, oxygen, nitrate, silicate,
DIC, and alkalinity for every model box (property budgets) comprise the set of model equations satisfied exactly by the model (hard constraints). These equations link the set of adjustable model parameters with a set of dependent parameters (predictions) that includes the vertical velocities and the simulated distributions of temperature, salinity, phosphate, oxygen, nitrate, silicate, DIC, and alkalinity. Given an initial set of adjustable parameters, the dependent parameters are uniquely determined by the model equations. The step of calculating the vertical velocities and model property fields is commonly referred to as a simulation.

Once calculated, one can compare the simulated property distributions with the measurements. Usually model/data comparison is done subjectively, and conclusions on possible causes and cures for model/data misfits lead to modification of adjustable parameters and to new simulations. While this approach is successful for box-models with a limited number of parameters, for large 3-D models like the present one, the manual adjustment of parameters is impractical and in most cases does not lead to desired improvements.

The so-called adjoint method is an alternative to manual parameter-tuning, and allows treatment of optimization problems with a large number of adjustable parameters like the present one (Hestenes, 1975; Thacker and Long, 1988; Schlitzer, 2000a). Here the evaluation of model/data misfits is performed automatically by means of a suitably formulated cost function (see Schlitzer (2000a) for a detailed discussion). A twin-model of the simulation step (the adjoint model) "learns" from the structure in the misfits and allows to calculate parameter modification, which when applied, leads to a better agreement between model and observations. Thus, the adjoint method guarantees improvement at each step of the iterative optimization procedure.

\subsection{Model experiments}

Table 1 shows the list of model experiments discussed in the present paper. These experiments differ with respect to P:N:C:O element ratios of the particulate and dissolved organic matter, the 
implementation of DOC and nitrification/ denitrification processes, the initial parameter set used, and the application of additional a priori constraints. Experiment $\mathrm{A}$ is the simplest experiment: it uses the classical element ratios of Redfield et al. (1963) and does not include DOC or nitrification/denitrification. Experiment B builds on the results from $\mathrm{A}$ and includes production and decay of semi-labile DOC in addition to particulate matter. Experiments $\mathrm{C}$ and $\mathrm{D}$ add complexity to the biogeochemical model by including nitrification/denitrification processes in a way described above. Experiment E was performed to test whether productivity patterns derived from satellite chlorophyll measurements are consistent with water-column oxygen, nutrient and carbon fields. For this purpose, the satellite-based primary productivity values of Antoine et al. (1996) were first converted to export production using the algorithm of Eppley and Peterson (1979), and the export values were then used in the constraints. Experiment $\mathrm{F}$ was initiated with the results from $\mathrm{E}$, but the a priori constraints of $\mathrm{E}$ were removed. This experiment was conducted to test whether the system tends back to the solution $\mathrm{C}$, which served as starting point for $\mathrm{E}$.

The last experiment, $G$, was initiated with results from $\mathrm{C}$ and includes DOC and nitrification/denitrification processes. As a significant advancement over previous experiments, $G$ is fitted to global chlorofluorocarbon (CFC) and natural radiocarbon $(\mathrm{C} 14)$ data WOCE DPC (2000), in addition to hydrography, oxygen, nutrient and carbon that are already used in the other experiments. $\mathrm{CFC}$ and $\mathrm{C} 14$ data were included mainly to exert further control over convection, water-mass formation, and bottomwater spreading in the Southern Ocean, which all appeared to be too vigorous in experiments $\mathrm{A}-\mathrm{F}$ (see Section 4).

\section{Results}

\subsection{Model/data misfits}

All model experiments listed in Table 1 were run until the decrease in the cost function was less than one per mille per 1000 iterations. The final states achieved in the different cases explain the hydrographic, oxygen, nutrient and carbon data to different degrees, and here the model/data misfits are critically evaluated to determine whether a particular experiment should be accepted or rejected. Mean and rms model misfits for various regions and depth ranges are discussed below. A summary of such deviations for oxygen, phosphate and nitrate in the Southern Ocean south of $50^{\circ} \mathrm{S}$ at depths between 150 and $750 \mathrm{~m}$ is provided in Table 2. This depth range was chosen because remineralization of POC and DOC is mainly confined to this part of the water column and unrealistic POC and DOC fluxes should lead to the largest misfits there.

The simplest experiment, A, also shows one of the largest overall misfit levels. While in general the simulated fields agree with observations and the model/data differences are considerably smaller than those obtained by other global biogeochemical models (Yamanaka and Tajika, 1996;

Table 2

Mean and rms deviations between model simulations and measurements for oxygen, phosphate and nitrate in the Southern Ocean south of $50^{\circ} \mathrm{S}$ in the depth range between 150 and $750 \mathrm{~m}$ for different model experiments

\begin{tabular}{|c|c|c|c|c|c|c|c|}
\hline \multirow[t]{2}{*}{ Experiment } & \multicolumn{2}{|c|}{ Oxygen $\left(\mu \mathrm{mol} \mathrm{kg}{ }^{-1}\right)$} & \multicolumn{2}{|c|}{ Phosphate $\left(\mu \mathrm{mol} \mathrm{kg}{ }^{-1}\right)$} & \multicolumn{2}{|c|}{ Nitrate $\left(\mu \mathrm{mol} \mathrm{kg}{ }^{-1}\right)$} & \multirow[b]{2}{*}{ Accepted } \\
\hline & Mean & $\mathrm{rms}$ & Mean & $\mathrm{rms}$ & Mean & $\mathrm{rms}$ & \\
\hline A & -6.8 & 26.5 & -0.05 & 0.21 & -0.7 & 3.9 & No \\
\hline $\mathrm{C}$ & -0.02 & 24.0 & 0.006 & 0.19 & 0.01 & 3.2 & Yes \\
\hline E & 2.3 & 25.0 & -0.03 & 0.21 & -0.54 & 3.6 & No \\
\hline $\mathrm{F}$ & -0.25 & 23.0 & 0.004 & 0.19 & -0.009 & 3.2 & Yes \\
\hline G & -0.20 & 21.5 & -0.004 & 0.17 & -0.14 & 2.2 & Yes \\
\hline
\end{tabular}


Maier-Reimer, 1993), there are still significant and systematic errors. For instance, phosphate concentrations in the surface layer are systematically too high by $0.11 \mu \mathrm{mol} \mathrm{kg}^{-1}$ (rms deviation $=$ $0.3 \mu \mathrm{mol} \mathrm{kg} \mathrm{kg}^{-1}$ ) when averaged over the whole model domain. In the Atlantic, the model phosphate overestimation is even larger and amounts to $0.20 \mu \mathrm{mol} \mathrm{kg}{ }^{-1}$ in the surface layer and to $0.16 \mu \mathrm{mol} \mathrm{kg}^{-1}$ when averaged over the top $500 \mathrm{~m}$ of the water column. Other misfits of experiment A include significant underestimation of oxygen in the Southern Ocean $\left(-25 \mu \mathrm{mol} \mathrm{kg}^{-1}\right.$ in the upper $150 \mathrm{~m}$ and $-6.8 \mu \mathrm{mol} \mathrm{\textrm {kg } ^ { - 1 }}$ between 150 and $750 \mathrm{~m}$ depth) and generally much higher (compared to experiments B-D and F) rms difference values for all properties. Because of the poor performance, especially in the Southern Ocean, experiment A is rejected and not included in the calculation of downward carbon transports presented below.

The high dissolved nutrient levels of experiment $A$ in the upper water-column are interpreted as a sign of missing dissolved organic matter (DOM). When DOM is added to the model, dissolved inorganic nutrients are used for the build-up of the DOM pool in addition to particulates, and nutrient levels fall to lower and more realistic values, especially in the upper water column, where DOM concentrations are highest. This is exactly what is observed for experiments $B-G$, which all include DOM. For experiment B, the surface overestimation of dissolved nutrients is reduced considerably (about $30 \%$ of $\mathrm{A}$ ), the oxygen deviations in the Southern Ocean are now of the order of $1-2 \mu \mathrm{mol} \mathrm{kg}{ }^{-1}$, and the overall rms deviations are much smaller compared to experiment A. Although experiment B still exhibits systematic property deviations in the low-latitude Pacific and Indian Ocean, which can be related to missing nitrification and denitrification processes, experiment $\mathrm{B}$ is accepted in the present context because of the realistic property simulations in the Southern Ocean.

Inclusion of nitrogen fixation and denitrification processes for experiments $\mathrm{C}$ and $\mathrm{D}$ leads to a further decrease in property misfits. Atlantic and Southern Ocean mean phosphate deviations are now smaller than $0.02 \mu \mathrm{mol} \mathrm{kg} \mathrm{kg}^{-1}$ everywhere, and the rms deviations range from $0.2 \mu \mathrm{mol} \mathrm{kg}^{-1}$ near the surface to about $0.08 \mu \mathrm{mol} \mathrm{kg} \mathrm{k}^{-1}$ at depth. Most of the rms deviations originate in areas of strong nutrient gradients where the model fields are too smooth because of limited horizontal and vertical resolution. Mean oxygen deviations are smaller than $1 \mu \mathrm{mol} \mathrm{kg}{ }^{-1}$, and rms deviations are between $10 \mu \mathrm{mol} \mathrm{kg}^{-1}$ in the upper water-column and $4 \mu \mathrm{mol} \mathrm{kg}^{-1}$ in the deep ocean. For nitrate there is still a small systematic error, the model being too high by about $0.2-0.7 \mu \mathrm{mol} \mathrm{kg}^{-1}$ above $2000 \mathrm{~m}$ depth and too low by about the same amount below $2000 \mathrm{~m}$. However, these effects are relatively small, and overall experiments $C$ and D explain the observations extremely well.

Model experiment E was conducted to test whether the model could accommodate export fluxes derived from the satellite-based productivity maps of Antoine et al. (1996), which turned out to be considerably smaller than the results for all the model experiments A-D (see below). E was run for about 50,000 iterations until the decrease in the cost function was less than one per mille per 1000 iterations, but the final state showed model/data property misfits for all properties that in some cases were even larger then for experiment A. Consequently, experiment E was rejected. The deterioration of model property fields was most severe in the Southern Ocean, where the additional constraints induced the largest productivity changes. Obviously, because the enforced productivity in the Southern Ocean was unrealistically small, the simulated nutrient concentrations were too high at the surface and too low at depths between 150 and $750 \mathrm{~m}$, where in a high-productivity situation nutrients would be released due to particle remineralization (see Table 2). There were also large deviations in the Southern Ocean silicate field, and a strong reduction in the strength of the meridional overturning cell in the South Atlantic, from $18 \mathrm{~Sv}$ for experiment $\mathrm{C}$ to $14.5 \mathrm{~Sv}$ for $\mathrm{E}$, shows that the model has to resort to drastic changes to accommodate a low-productivity Southern Ocean suggested by satellite observations.

When the low-productivity model state E is used and run further after removing the productivity constraints (experiment $\mathrm{F}$ ), the model restores most of the higher export production in the 
Southern Ocean, as found in experiments A-D. Model/data misfits are of similar size as for B and $\mathrm{C}$, and experiment $\mathrm{F}$ is considered a realistic solution.

In the context of the Ocean Carbon Model Intercomparison Project (OCMIP) experiments $\mathrm{A}-\mathrm{F}$ were used to simulate oceanic chlorofluorocarbon (CFC) and natural radiocarbon (C14) distributions. Among the 13 global models involved in the comparison, the AWI model achieved relatively small overall CFC misfits and was the only one to reproduce such features as the double sub-surface CFC maxima associated with the deep western boundary current in the North Atlantic and the CFC maxima associated with the formation Antarctic Intermediate Water (AAIW) and Antarctic Bottom Water (AABW) in the Southern Ocean (Dutay et al., 2002). Nevertheless, systematic errors remain, especially in the AABW, where too high CFC concentrations indicate too vigorous convection and/or bottom water formation in the Southern Ocean. In addition, simulations of natural $\mathrm{C} 14$ show too high concentrations in the deep Pacific, which could also be explained by unrealistically high convection and bottomwater spreading rates.

Because the intensity of vertical convection strongly affects the nutrient supply to the euphotic zone and thus biological production, a new model solution $G$ was sought that satisfies hydrography, nutrients and carbon but also yields realistic $\mathrm{CFC}$ and $\mathrm{C} 14$ distributions (CFC/C14 fitting procedure described elsewhere). Experiment $\mathrm{G}$ was initiated with results from $\mathrm{C}$ and run for about 100,000 iterations until the cost function decrease was below the usual stopping criteria (see above). For solution G, the CFC simulations agree well with observations; for instance, in the eastern Weddell Sea where CFC deviations in the bottom-water at the Greenwich meridian in experiment $\mathrm{C}$ for 1984 reached up to $0.8 \mathrm{pmol} \mathrm{kg}^{-1}$ (1. instead of $0.23 \mathrm{pmol} \mathrm{kg}^{-1}$ observed; Warner and Weiss, 1992), for G CFC values are only $0.04 \mathrm{pmol} \mathrm{kg}^{-1}$ too high. Also, the model $\mathrm{C} 14$ values in the deep Pacific now agree with measurements: instead of being too high by about $60 \%$ in northeast Pacific bottom waters ( -160 instead of observed $-220 \%$; Stuiver et al.,
1983; Key et al., 1996), in G the model C14 misfit is only about $+4 \%$.

The additional requirement in $\mathrm{G}$ of reproducing CFC and $\mathrm{C} 14$ distributions resulted in slightly larger overall misfits in the hydrographic, nutrient and carbon fields compared to experiment $\mathrm{C}$, which served as initial field for run G. However, these increases are relatively small and the corresponding cost function terms remain smaller than those for the rejected experiments $\mathrm{A}$ and $\mathrm{E}$. Consequently, experiment $\mathrm{G}$ was accepted as agreeing with global tracer observations.

The mean and rms deviations for the Southern Ocean south of $50^{\circ} \mathrm{S}$ in the depth range between 150 and $750 \mathrm{~m}$ (where most of the POC remineralization occurs) confirm the rejection of experiments $\mathrm{A}$ and $\mathrm{E}$. Those experiments show the largest rms differences and also exhibit the largest systematic misfits.

\subsection{DOC distribution}

Fig. 4 shows the simulated distribution of semilabile dissolved organic carbon DOC in southern hemisphere near the surface and at $500 \mathrm{~m}$ depth. The simulation is for experiment $\mathrm{C}$ and uses a DOC production rate equal to the export flux of particulate organic carbon $\left(r_{\mathrm{D} / \mathrm{P}}=1\right)$ and a lifetime of $\tau_{\mathrm{D}}=2$ yrs. From the surface plot (Fig. 4a) it can be seen that with the specified production and decay parameters, semi-labile DOC concentrations between 30 and $40 \mu \mathrm{mol} \mathrm{kg}{ }^{-1}$ can be attained in mid and low latitudes with only small horizontal gradients between areas of high or low productivity, in agreement with present observations. In the Southern Ocean, however, the surface DOC concentrations are considerably lower and the average value for the area south of $50^{\circ} \mathrm{S}$ is about $15 \mu \mathrm{mol} \mathrm{kg} \mathrm{k}^{-1}$. These lower DOC concentrations are in good agreement with measurements of Ogawa et al. (1999), Wiebinga and de Baar (1998), and Kaehler et al. (1997), which all show reduced levels between 5 and $20 \mu \mathrm{mol} \mathrm{kg}{ }^{-1}$ for semi-labile DOC in the Southern Ocean. In the model, this is due to the contributions of upwelled water from below, which supplies dissolved inorganic nutrients but little or no DOC. 

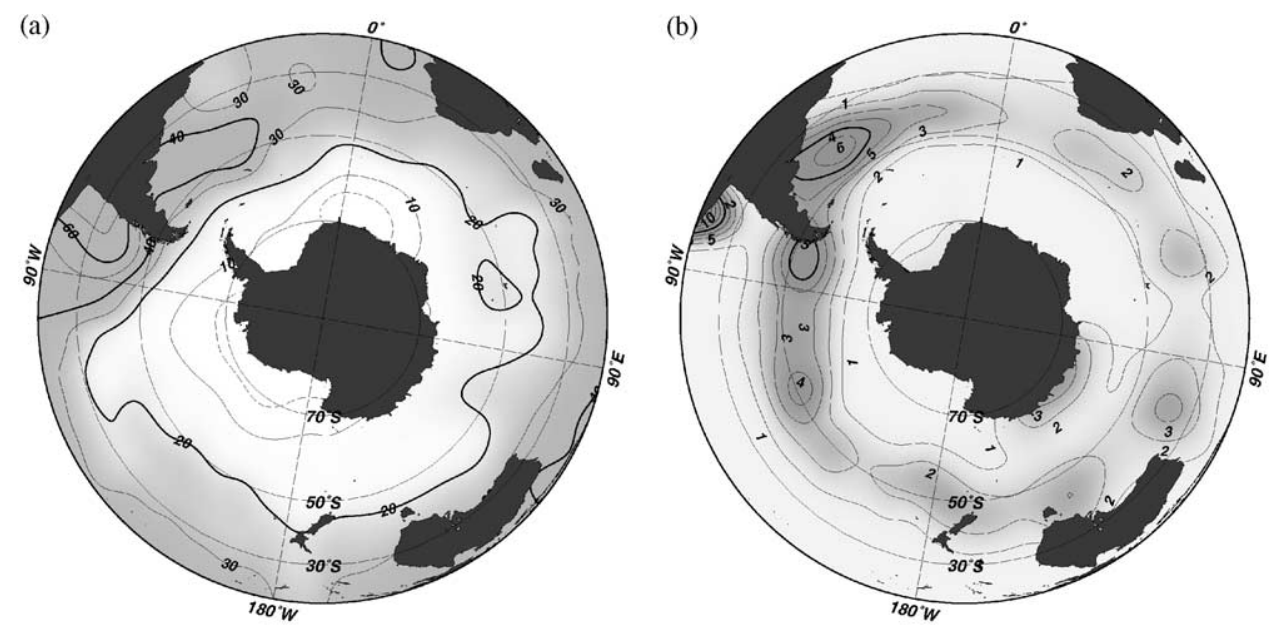

Fig. 4. Distribution of semi-labile DOC $\left(\mu \mathrm{mol} \mathrm{kg}{ }^{-1}\right)$ in the southern hemisphere (a) in the model surface layer (30 $\mathrm{m} \mathrm{depth)}$ and (b) in $500 \mathrm{~m}$ depth. The simulation is for experiment $\mathrm{C}$ and uses a DOC production rate equal to the POC export flux $\left(r_{\mathrm{D} / \mathrm{P}}=1\right)$ and a lifetime $\tau_{\mathrm{D}}=2 \mathrm{yrs}$.

At $500 \mathrm{~m}$ depth (Fig. 4b), DOC concentrations are about one order of magnitude smaller than surface values (in general agreement with observations), and elevated levels are only found in regions of deep-water formation along the Antarctic margin (model deep-water formation sites are in the Weddell Sea and at about $120^{\circ} \mathrm{E}$ ) and in the area of intermediate water formation and subduction between $40^{\circ} \mathrm{S}$ and $50^{\circ} \mathrm{S}$. The field in $500 \mathrm{~m}$ depth reveals regions of downward transport of DOC associated with water mass formation. These fluxes are quantified and compared with the downward transport of particulate material in the next section.

\subsection{Export production}

The model export fluxes for POC from experiment $\mathrm{C}$, which (as described above) explains the observed hydrography and dissolved nutrient, oxygen and carbon distributions in the world ocean, are shown for the southern hemisphere in Fig. 5. It should be noted that these fluxes represent long-term annual mean values, and that because of high spatial and temporal variability especially at high latitudes direct observations from specific years could deviate from these estimates. In the model solution, high-productivity areas are found in the tropical Indian and Pacific Ocean, in the coastal upwelling regions off Chile, Peru and Namibia, on the Patagonian shelf, and in a circum-Antarctic zonal band between about $40^{\circ} \mathrm{S}$ and $60^{\circ} \mathrm{S}$, which roughly corresponds with the Antarctic Circumpolar Current (ACC) band. Highest export fluxes are found in the Peru/Chile upwelling region, with values exceeding $150 \mathrm{gC} \mathrm{m}^{-2} \mathrm{yr}^{-1}$, and on and east of the Patagonian shelf as well as in the Namibia upwelling area, where values reach up to $80 \mathrm{gC} \mathrm{m}^{-2} \mathrm{yr}^{-1}$. In the circum-Antarctic productivity belt, average export fluxes are of the order of $30 \mathrm{gC} \mathrm{m}^{-2} \mathrm{yr}^{-1}$, whereas in the seasonally or permanently ice-covered regions of the Weddell and Ross Seas carbon export fluxes are around or below $5 \mathrm{gC} \mathrm{m}^{-2} \mathrm{yr}^{-1}$.

The other accepted model solutions $\mathrm{B}$ and $\mathrm{D}$ have export production patterns that are very similar to solution $\mathrm{C}$, with only small differences in the magnitudes of the fluxes. Solution F, which is also considered a valid solution, but was run with smaller weights on the horizontal smoothness constraints, yields an export production map with higher spatial variability. Unlike solution C, experiment $\mathrm{F}$ shows local areas of elevated export production in the Ross Sea (about $\left.10 \mathrm{gC} \mathrm{m}^{-2} \mathrm{yr}^{-1}\right)$, eastern, coastal Weddell Sea (about $13 \mathrm{gC} \mathrm{m}^{-2} \mathrm{yr}^{-1}$ ), and in the southern 


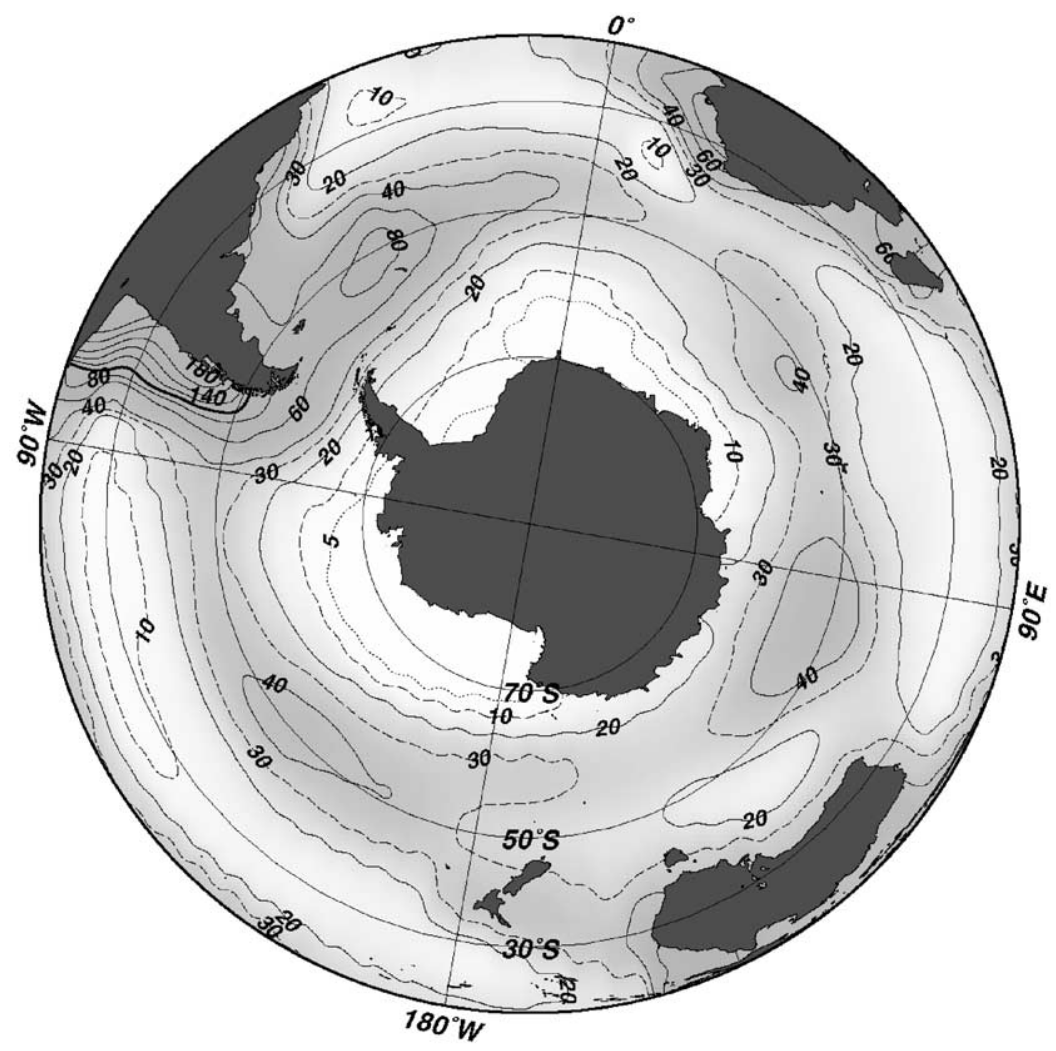

Fig. 5. Export production of particulate organic carbon POC $\left(\mathrm{gC} \mathrm{m}^{-2} \mathrm{yr}^{-1}\right)$ in the southern hemisphere for experiment C. Together with a 3-D model circulation that is consistent with present knowledge, this field explains the oxygen, nutrient and carbon observations very well.

Bellingshausen Sea along the Antarctic Peninsula (about $67^{\circ} \mathrm{S} / 70^{\circ} \mathrm{W}$; about $25 \mathrm{gC} \mathrm{m}^{-2} \mathrm{yr}^{-1}$ ).

The globally integrated export flux for experiment $\mathrm{C}$ amounts to $9630{\mathrm{TgC} \mathrm{yr}^{-1}}^{-1}$ (equivalent to

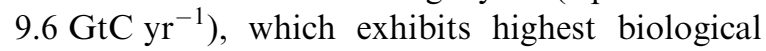
activity in tropical and sub-tropical areas between $30^{\circ} \mathrm{S}$ and $30^{\circ} \mathrm{N}\left(5340 \mathrm{TgC} \mathrm{yr}^{-1}\right)$, followed by contributions from the Southern Ocean south of $30^{\circ} \mathrm{S}\left(2970 \mathrm{TgC}^{-1}\right)$. With an export flux of $1320 \mathrm{TgC} \mathrm{yr}^{-1}$ the region north of $30^{\circ} \mathrm{N}$ makes only a relatively small contribution to the total flux. Averaged over oceanic areas, however, the export fluxes for these three regions are surprisingly similar: $24.8 \mathrm{gC} \mathrm{m}^{-2} \mathrm{yr}^{-1}$ for the northern hemisphere north of $30^{\circ} \mathrm{N}, 28.7 \mathrm{gC} \mathrm{m}^{-2} \mathrm{yr}^{-1}$ for the tropical/subtropical band between $30^{\circ} \mathrm{S}$ and $30^{\circ} \mathrm{N}$, and $27.6 \mathrm{gC} \mathrm{m}^{-2} \mathrm{yr}^{-1}$ for the southern hemisphere south of $30^{\circ} \mathrm{S}$. Thus, within model uncertainty (described below), the per area contribution of the Southern Ocean to the global carbon export is of about equal size as the contribution of the low and mid-latitudes. These model results suggest that describing the Southern Ocean as a low-productivity region seems inappropriate.

\subsection{Vertical fluxes}

For a quantitative comparison with literature values, the area of the Southern Ocean south of $50^{\circ} \mathrm{S}$ is now analyzed in detail. It should be noted, however, that the sub-division at $50^{\circ} \mathrm{S}$ is arbitrary and to some extent misleading, because significant export fluxes just north of the selected area are left out of the transport estimation (see Fig. 5). Please note that the total export fluxes would be about 

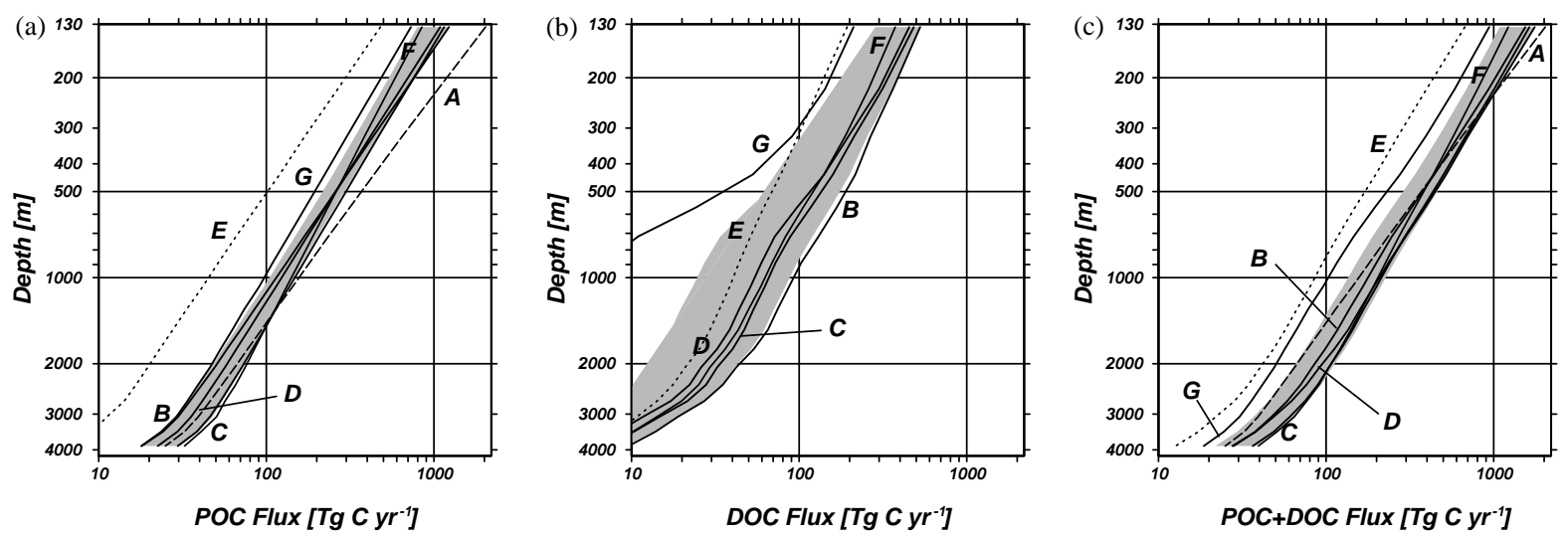

Fig. 6. Downward carbon fluxes in the Southern Ocean south of $50^{\circ} \mathrm{S}$ for the different model experiment versus depth: (a) flux of particulate organic carbon POC, (b) flux of dissolved organic carbon DOC, and (c) flux of total organic carbon POC plus DOC. The gray-shaded areas represent the accepted value ranges. For a description of the different experiments, see Table 1 and the text.

twice as high, if the region under consideration would be extended to $40^{\circ} \mathrm{S}$.

The integrated downward fluxes of POC for the Southern Ocean south of $50^{\circ} \mathrm{S}$ are shown in Fig. 6a. Except for depths greater than about $3000 \mathrm{~m}$, the flux profiles show a power function decrease with depth. While each individual particle flux profile in the model follows Eq. (1), this need not necessarily be the case for a regional integral, as is evident from deviations below about $3000 \mathrm{~m}$ depth, for which fewer and fewer model columns make a contribution. Values for the parameter $b$ in (1) representative for the Southern Ocean south of $50^{\circ} \mathrm{S}$ estimated by fitting curves of the form (1) to the profiles in Fig. 6a are summarized in Table 3.

The largest value $b=1.288$ is found for experiment A. This experiment does not include DOC and appears to compensate this lack by an excess of particulate material especially in the upper part of the water-column (Fig. 6a) where DOC concentrations are highest. Because experiment $\mathrm{A}$ was rejected, and obviously includes effects of dissolved components in the particulate phase, the large $b$ is not considered to describe the vertical decrease of POC correctly. For the other experiments that include DOC, the values for $b$ are significantly smaller and for the accepted model runs $\mathrm{B}-\mathrm{D}, \mathrm{F}$ and $\mathrm{G}$ range from 0.901 to 1.183 . The average value, $b=1.04$, is still significantly higher than the estimate of Martin et al. (1987) (0.856)
Table 3

Values for exponent $b$ in Eq. (1) for the total POC fluxes in the Southern Ocean south of $50^{\circ} \mathrm{S}$ for the various model experiments (see Fig. 6a). The average of the accepted experiments B, $\mathrm{C}, \mathrm{D}, \mathrm{F}$, and $\mathrm{G}$ is $b=1.04$

\begin{tabular}{ll}
\hline Experiment & $b$-Value \\
\hline A & 1.288 \\
B & 1.183 \\
C & 1.025 \\
D & 1.088 \\
E & 1.176 \\
F & 0.901 \\
G & 1.010 \\
\hline
\end{tabular}

and somewhat higher than the value of Suess (1980) (1.0). The observed differences in the estimated $b$ values may seem small, however, because of the steepness of Eq. (1) in the upper water-column, they lead to significant differences in estimated deep water fluxes. Assuming the same export flux out of the euphotic zone, the model predicts a particle flux at $1000 \mathrm{~m}$ depth, that is about $35 \%$ smaller than what would be obtained with the Martin et al. (1987) value, and still a 10\% smaller flux in the Suess (1980) case.

Model experiments A and E, which have been rejected because of too large property misfits (see above), stand out in Fig. 6a because of their high (A) or low (E) particle fluxes. Compared to the whole range of fluxes between curves $\mathrm{A}$ and $\mathrm{E}$, the 
range of accepted particle fluxes from experiments $\mathrm{B}$ to $\mathrm{D}, \mathrm{F}$ and $\mathrm{G}$ (gray-shaded area) is relatively narrow, and uncertainties amount to between $20 \%$ and $35 \%$. The smallest relative errors are obtained in the depth range between 200 and $800 \mathrm{~m}$ depth, which is also the place of largest gradients in the property data that are used by the model. Average particle fluxes and standard deviations for the experiments B-D, F and $\mathrm{G}$ are summarized in Table 4 for different depths. The model calculates an average POC export flux for the Southern Ocean south of $50^{\circ} \mathrm{S}$ of $1000 \pm 210 \mathrm{TgC} \mathrm{yr}^{-1}$. About $90 \%$ of the exported particles are remineralized within the top $1000 \mathrm{~m}$ of the water column, and the flux at $1078 \mathrm{~m}$ depth is reduced to $115 \pm 20{\mathrm{TgC} \mathrm{yr}^{-1}}^{-}$. At about $4000 \mathrm{~m} \mathrm{depth}$, the particle flux amounts to only $2.5 \%$ of the export. Note that solution $\mathrm{G}$, which has been fitted to CFC and C14 data in addition to hydrography and nutrients, shows the smallest particle fluxes of all accepted experiments, but these smaller particle fluxes are still between $60 \%$ and $300 \%$ higher than fluxes corresponding to satellite productivity estimates (E).

\section{Table 4}

Mean POC, DOC and POC + DOC fluxes in the Southern Ocean south of $50^{\circ} \mathrm{S}$, and standard deviations for model experiments $\mathrm{B}, \mathrm{C}, \mathrm{D}, \mathrm{F}$, and $\mathrm{G}$ for different depths. $1000{\mathrm{TgC} \mathrm{yr}^{-1}}^{-}$are equivalent to $10^{15} \mathrm{~g} \mathrm{C} \mathrm{yr}^{-1}$ or $1 \mathrm{GtC} \mathrm{yr}^{-1}$

\begin{tabular}{|c|c|c|c|}
\hline $\begin{array}{l}\text { Depth } \\
\text { (m) }\end{array}$ & $\begin{array}{l}\text { POC flux } \\
\left(\mathrm{TgC} \mathrm{yr}^{-1}\right)\end{array}$ & $\begin{array}{l}\text { DOC flux } \\
\left(\operatorname{TgC~} \mathrm{yr}^{-1}\right)\end{array}$ & 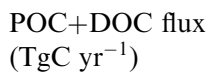 \\
\hline 133 & $1000 \pm 210$ & $410 \pm 125$ & $1410 \pm 330$ \\
\hline 219 & $600 \pm 100$ & $275 \pm 80$ & $875 \pm 190$ \\
\hline 320 & $400 \pm 60$ & $190 \pm 65$ & $590 \pm 120$ \\
\hline 436 & $290 \pm 40$ & $140 \pm 60$ & $430 \pm 95$ \\
\hline 568 & $220 \pm 30$ & $100 \pm 50$ & $320 \pm 80$ \\
\hline 719 & $175 \pm 25$ & $75 \pm 40$ & $250 \pm 60$ \\
\hline 888 & $140 \pm 20$ & $62 \pm 35$ & $202 \pm 50$ \\
\hline 1078 & $115 \pm 20$ & $52 \pm 30$ & $167 \pm 42$ \\
\hline 1289 & $95 \pm 17$ & $45 \pm 25$ & $140 \pm 35$ \\
\hline 1522 & $81 \pm 15$ & $40 \pm 22$ & $121 \pm 32$ \\
\hline 1779 & $69 \pm 14$ & $33 \pm 18$ & $102 \pm 27$ \\
\hline 2060 & $59 \pm 13$ & $26 \pm 15$ & $85 \pm 22$ \\
\hline 2368 & $51 \pm 12$ & $22 \pm 12$ & $73 \pm 20$ \\
\hline 2702 & $44 \pm 10$ & $17 \pm 10$ & $61 \pm 16$ \\
\hline 3064 & $38 \pm 10$ & $12 \pm 7$ & $50 \pm 13$ \\
\hline 3456 & $31 \pm 8$ & $9 \pm 5$ & $40 \pm 10$ \\
\hline 3879 & $24 \pm 7$ & $6 \pm 4$ & $31 \pm 8$ \\
\hline
\end{tabular}

The distribution of DOC at $500 \mathrm{~m}$ depth in Fig. $4 \mathrm{~b}$ indicates a net downward carbon transport in the DOC pool in the Southern Ocean, in addition to the downward transport by particles. The calculated vertical DOC transports for the different model solutions are shown in Fig. $6 \mathrm{~b}$ and Table 4. Whereas globally the relative size of downward DOC fluxes compared to particle fluxes decreases rapidly with depth, from about $30 \%$ at the base of the euphotic zone to $5 \%$ at $1078 \mathrm{~m}$ depth (see also Schlitzer, 1989), the situation is different in the Southern Ocean. For model solutions B-D and F, the formation and subduction of intermediate, deep and bottom water lead to considerable downward transport of DOC, which at the base of the euphotic zone is comparable in relative importance with the global estimate (DOC flux amounts to about $45 \%$ of the particle flux), but stays high with increasing depths. At about $1000 \mathrm{~m}$ depth, the DOC flux amounts to about $50 \%$ and at $3879 \mathrm{~m}$ depth it is still about $25 \%$ of the particle flux. In the light of the excessively high CFC bottom water values in these solutions, it seems likely that the downward DOC fluxes into the deep water are overestimated as well. This is confirmed by solution $\mathrm{G}$, for which the DOC fluxes decrease rapidly below about $500 \mathrm{~m}$ depth. The results from $\mathrm{G}$ have to be considered lower limits for the DOC fluxes because the simulated DOC concentrations in the upper water column obtained with relatively small particle fluxes (see Fig. 6a) and $r_{\mathrm{D} / \mathrm{P}}=1, \tau_{\mathrm{D}}=2$ [yrs] (see Section 3.2) are about 50\% smaller than measured values.

The total downward flux of particulate plus semi-labile dissolved organic carbon is shown in Fig. 4c, and numerical values for different depths are given in Table 4. The POC + DOC export flux at the base of the euphotic zone amounts to $1410 \pm 330 \mathrm{TgC}^{-1}$. The transport decrease with depth is rapid and can accurately be fitted by a function of type (1) with an exponent $b=1.007$. This value for $b$ is very close to the result obtained by Suess (1980) for particles alone. It should be noted that the total downward carbon flux in the upper $500 \mathrm{~m}$ in experiment $\mathrm{A}$, which does not include DOC, agrees rather well with the experiments that explicitly model POC and DOC. 


\subsection{Comparison with satellite-based estimates}

The high export production in a circumAntarctic band, which is seen in all acceptable model solutions (see Fig. 5), contrasts with productivity results based on pigment or chlorophyll observations from satellites, which show relatively low production in the Southern Ocean south of $50^{\circ} \mathrm{S}$ (Longhurst et al., 1995; Antoine et al., 1996; Behrenfeld and Falkowski, 1997; Arrigo et al., 1998). This discrepancy between satellite-based estimates and model findings based on nutrient observations and budgets in the ocean interior has been noted by Schlitzer (2000a), using a previous solution of the model without DOC and nitrogen fixation/denitrification. These discrepancies persist for a more complex biogeochemical model with even more realistic simulations of the global oxygen, nutrient and carbon fields and also for a model solution that closely reproduces the global CFC and natural radiocarbon data.

To compare the productivity results of the two approaches, the satellite-based primary productivity values have been converted to export production values using the formula of Eppley and Peterson (1979). The ratios of model-derived and satellite-derived export fluxes are displayed in Fig. 7 for three different satellite productivity estimates. Figs. 7a and $b$ use annual productivity fields of Behrenfeld and Falkowski (1997) (their Figs. 9A and B), which are based on annual mean chlorophyll data from the Coastal Zone Color Scanner (CZCS) sensor on the NIMBUS-7 satellite and a light-dependent, depth-resolved model for carbon fixation (VGPM). The difference between the two fields is in the temperature dependence of the parameter $P_{\mathrm{opt}}^{B}$ that describes

Fig. 7. Maps of the ratio of model POC export fluxes and satellite-derived export fluxes in the Southern Ocean for (a) annual productivity field of Behrenfeld and Falkowski (1997) (Fig. 9A), (b) annual productivity field of Behrenfeld and Falkowski (1997) (Fig. 9B), and (c) productivity estimates using the VGPM model of Behrenfeld and Falkowski (1997) with the SeaWiFS data from September 1998 to August 1999 (M. Behrenfeld, pers. comm.). The satellite-based export fluxes were calculated from primary productivity values using the Eppley and Peterson (1979) equation.
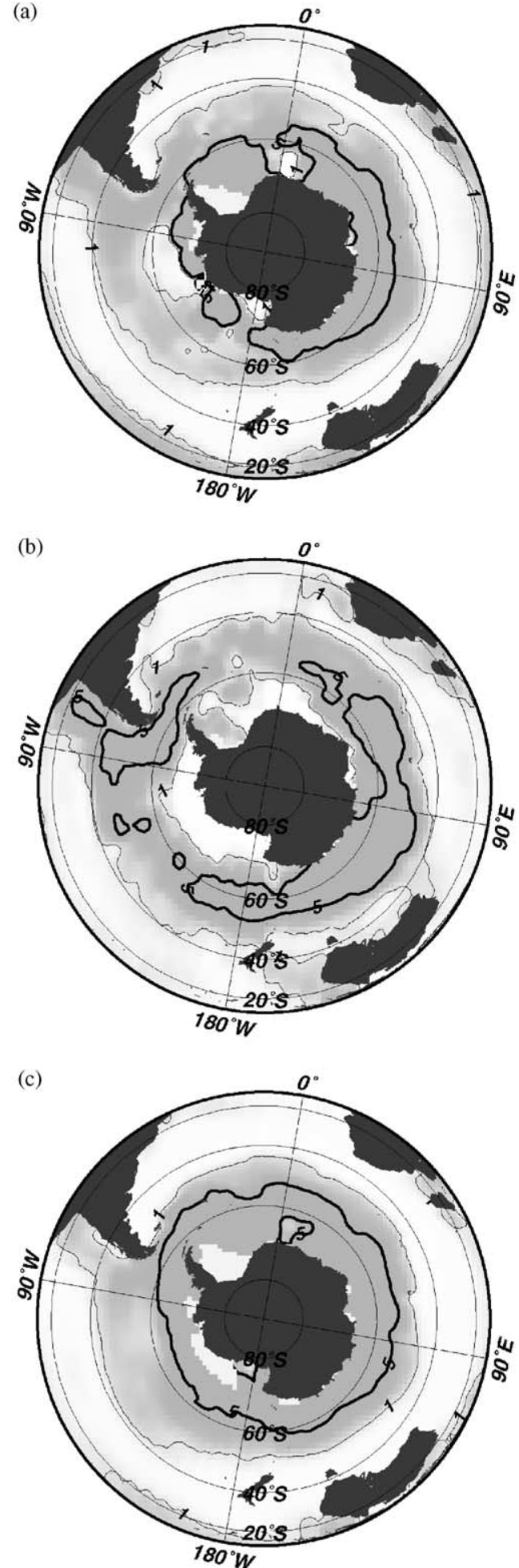
the optimal assimilation efficiency of the productivity profile. Whereas an empirical relationship between measured $P_{\mathrm{opt}}^{B}$ and sea surface temperature was used for Fig. 7a, Fig. 7b applies the theoretical exponential temperature-dependent model of Eppley (1972), which leads to lower $P_{\text {opt }}^{B}$ values for sea-surface temperatures below $20^{\circ}$. Fig. 7c is based on chlorophyll measurements from the SeaWiFS satellite from September 1998 to August 1999 and the empirical temperature dependence of the $P_{\mathrm{opt}}^{B}$ parameter (M. Behrenfeld, pers. commun.).

For all three cases, the model export production is systematically higher than the satellite-based productivity estimates in the Southern Ocean south of $50^{\circ} \mathrm{S}$ (see gray-shaded areas in Figs. 7a$\mathrm{c}$ with ratios $>1$ ). The observed differences are significant and can reach a factor of 5 south of $60^{\circ} \mathrm{S}$. Similar systematic differences between the model and satellite-based productivity estimates have been found for other studies using CZCS data (Longhurst et al., 1995; Antoine et al., 1996 as well as for the SeaWiFS data from September 1997 to August 1998 (M. Behrenfeld, pers. comm.). For model experiment $\mathrm{G}$ with its smaller POC fluxes, the productivity differences are smaller than for experiment C. However, even in this case a zonal band with ratios as high as 4 is found south of $50^{\circ} \mathrm{S}$, indicating that the discrepancy between the two approaches is fundamental and independent of the specific satellite sensor used. The fact that model and satellite estimates agree much better in mid- and low-latitudes as well as in the North Pacific and North Atlantic suggests that explanations specific for the Southern Ocean have to be sought. The subject is further addressed in the next section, and possible explanations are discussed.

\section{Summary and discussion}

A global circulation, biogeochemical model that includes production and subsequent decay of particulate and dissolved organic material as well as nitrogen fixation and denitrification processes can explain the observed distributions of hydrographic parameters, oxygen, dissolved nutrients, and carbon in the world ocean extremely well. Finding realistic solutions for complex models like the present one would not have been possible manually and could only be achieved with the help of the adjoint method, which provides an efficient tool for driving models towards data.

A common characteristic of all accepted model solutions is their relatively high biological productivity in the Southern Ocean. Of the approximately $10,000{\mathrm{TgC} \mathrm{yr}^{-1}}^{-1}$ of export production required globally, the Southern Ocean south of $30^{\circ} \mathrm{S}$ contributes about $3000{\mathrm{TgC} \mathrm{yr}^{-1}}^{-1}(33 \%)$, most of which occurs in a zonal belt along the Antarctic Circumpolar Current and in the Peru, Chile and Namibia coastal upwelling regions. The export flux of POC south of $50^{\circ} \mathrm{S}$ still amounts to $1000 \pm 210{\mathrm{TgC} \mathrm{yr}^{-1}}^{-}$. The decrease of the particle fluxes with depth is rapid, indicating strong remineralization at shallow depths. A fit of the particle flux profiles with a power-law relationships of form (1), reveals an average exponent $b=$ 1.04 , which is significantly larger than the value 0.856 of Martin et al. (1987) and, for the same export production, results in smaller particle fluxes into the deep ocean. Unlike for the global ocean, the downward transport of DOC in the Southern Ocean makes a significant contribution to the vertical carbon flux in the upper $500 \mathrm{~m}$ of the water column.

When comparing model export fluxes with export production derived from satellite productivity maps, there is a relatively good agreement in low- and mid-latitudes and in the North Pacific and North Atlantic, but in the Southern Ocean the model is found to be systematically higher, independent of whether CZCS or SeaWiFS data are used and independent of the specific parameters used for the chlorophyll-to-productivity conversion algorithms. This discrepancy would be even larger if the model fluxes at $133 \mathrm{~m}$ depth were corrected using (1) to shallower depths of the euphotic zone (factor 1.3 for $z_{\mathrm{EZ}}=100 \mathrm{~m}$ ).

Model experiment $\mathrm{E}$ was constructed to test the hypothesis that a low-productivity Southern Ocean, as suggested by the satellite maps, could be consistent with ocean interior nutrient budgets and could yield realistic property fields with misfits as low as for the other accepted solutions. For 
non-linear problems, like the present one, as yet undiscovered solutions in parts of the parameter space that have not been searched by the optimization procedure cannot be ruled out from the outset, because multiple local minima (solutions) may exist.

To test the hypothesis, a low export production in the Southern Ocean was enforced for experiment $\mathrm{E}$ by applying additional constraints, while adjusting the model 3-D flow field, the air-sea gas exchange rates, and remineralization parameters $b$. The achieved, best model state in a low-productivity Southern Ocean yielded large property misfits, especially in the Southern Ocean (see above). Thus, experiment $\mathrm{E}$ had to be rejected, and no realistic solution with small export production as from satellite estimates could be found. Furthermore, when calculations were continued (experiment F) with model state $\mathrm{E}$, but without the satellite productivity constraints, the export production in the Southern Ocean rose

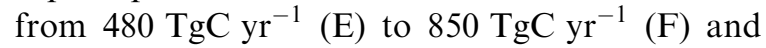
reached about $80 \%$ of the export flux of the common parent experiment $\mathrm{C}$ (see Fig. 6a). This is additional evidence that the small export fluxes derived from satellite productivity maps in the Southern Ocean are inconsistent with observed nutrient distributions.

Experiment $\mathrm{G}$, which produces realistic distributions for CFC and C14 in addition to hydrography and nutrients and exhibits a reduced intensity of convection in the Southern Ocean, shows smaller POC fluxes than the other accepted experiments ( $730{\mathrm{TgC} \mathrm{yr}^{-1}}$ south of $\left.50^{\circ} \mathrm{S}\right)$. This is probably the result of a reduced upward nutrient supply into the euphotic zone. However, even for this experiment, the model POC export is systematically and significantly higher than corresponding satellite estimates in the Southern Ocean south of $50^{\circ} \mathrm{S}$.

In principle, the discrepancy between the two approaches could be explained by an inappropriate conversion of satellite primary production to export production, which was performed for the comparison in Fig. 7. The method of Eppley and Peterson (1979) was used for this purpose, which assumes that the $f$-ratio (ratio of export production to primary production) is a monotonically increasing function of primary production with a maximum value of 0.5 for primary production rates above about $300 \mathrm{gC} \mathrm{m}^{-2} \mathrm{yr}^{-1}$. Recently, Laws et al. (2000) have questioned this simple picture, and they argue that the $f$-ratio depends on temperature as well as on total production. $f$ values in their case still increase with primary production, but the maximum levels depend on temperature and are highest $\left(f_{\max }=0.67\right)$ at low temperatures. While the larger achievable $f$ in cold waters $(0.67$ versus 0.5$)$ potentially could (for high primary production values) lead to larger export fluxes in the Southern Ocean as compared to the Eppley and Peterson (1979) case, for the low, satellite-derived primary production levels the export fluxes in the Southern Ocean are still low, even if the Laws et al. (2000) $f$-ratios are used (see their Plate 6).

Fig. 8 shows the ratios of model export fluxes and satellite primary production (model " $f$ ratios") for experiment $\mathrm{C}$ and the primary production estimates already used for Fig. 7. While in the areas north of $40^{\circ} \mathrm{S}$ the model " $f$ ratios" are compatible with Eppley and Peterson (1979) or Laws et al. (2000) estimates, the common feature for all cases is the presence of large values in the Southern Ocean south of $40^{\circ} \mathrm{S}$, exceeding the maximum theoretical values 0.5 or 0.67 , respectively. Over large areas of the Southern Ocean the model export fluxes are even higher than the satellite-based primary production values.

Due to changing light conditions, ice cover and vertical stratification, biological productivity in the Southern Ocean varies seasonally, with most of the downward particle flux occurring during the southern hemisphere summer. Could the lack of temporal resolution of the present model (see Section 3) therefore lead to an overestimation of the POC export and thus explain the discrepancy with satellite-based productivity values? Consistent with the picture of nutrient drawdown by biological activity, phosphate values are lowest during the productive summer season $\left(1.25 \mu \mathrm{mol} \mathrm{kg}^{-1}\right)$ and highest during winter $\left(2 \mu \mathrm{mol} \mathrm{kg}{ }^{-1}\right)$ (Fig. 9). Considering a zonal integral, the surface-water nutrient budget of the Southern Ocean (see Fig. 9c) can be expressed as a balance between nutrient supply from below, 

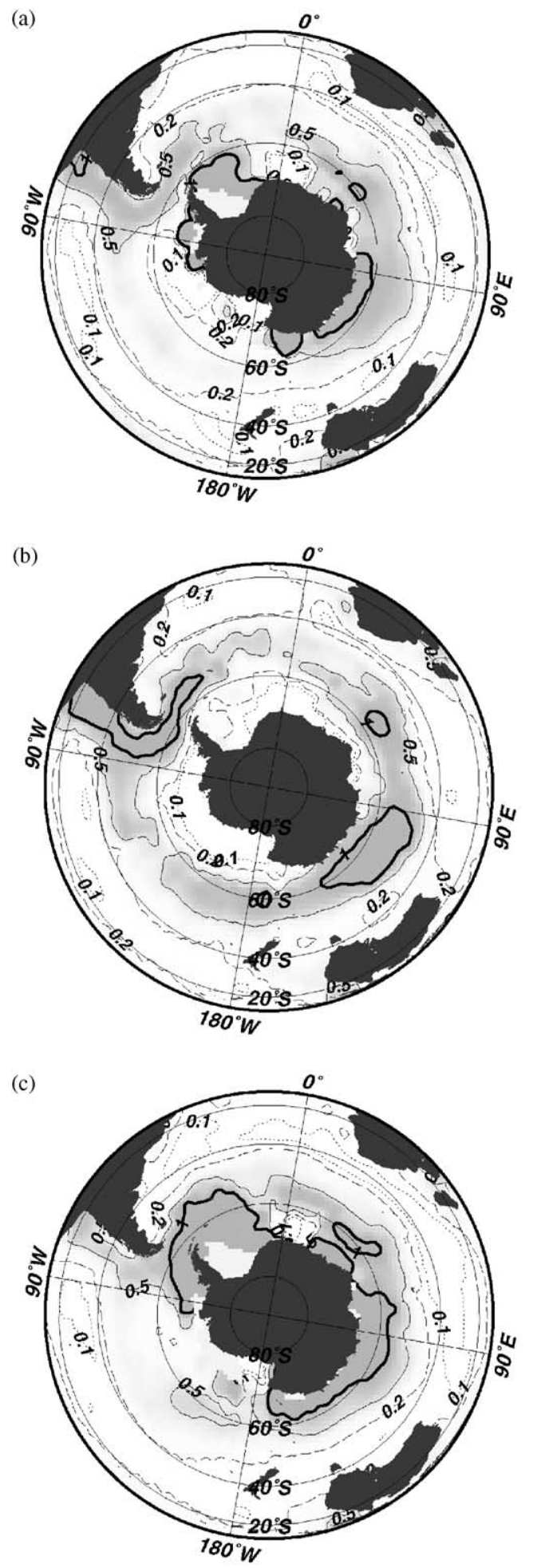

advective nutrient loss by northward Ekman flows, downward nutrient loss due to sinking particles, and temporal concentration change:

$j\left(C_{\mathrm{D}}-C_{\mathrm{S}}(t)\right)-E P(t)=V \frac{\partial C_{\mathrm{S}}(t)}{\partial t}$.

In (2), $V$ is the volume of the surface box, $j$ is the upwelling rate, $E P(t)$ is the export flux, and $C_{\mathrm{D}}$ and $C_{\mathrm{S}}(t)$ are the deep- and surface-water nutrient values, respectively. When integrated over a whole year, the temporal change term on the right-handside vanishes, and we are left with a budget that involves mean surface-nutrient concentrations $\overline{C_{\mathrm{S}}(t)}$ and mean particle fluxes $\overline{E P}$ only:

$j\left(C_{\mathrm{D}}-\overline{C_{\mathrm{S}}}\right)-\overline{E P}=0$.

Downward particle fluxes in the present model are calculated on the basis of the annually averaged budget equations (3), and, as long as the model manages to reproduce realistic mean surface nutrient concentrations, it should correctly represent annually averaged downward particle fluxes. Mean surface-nutrient deviations for the whole model domain are actually very small in all accepted model solutions, and for phosphate amount to between -0.04 and $-0.08 \mu \mathrm{mol} \mathrm{kg}{ }^{-1}$. In the polar and sub-polar regions, the data are biased towards the respective summer seasons and do not represent true mean values. If the model would accurately match the seasonally biased data, the resulting export fluxes would indeed overestimate the mean fluxes. However, it is a common feature of all model solutions (see also Heras and Schlitzer, 1999) that in areas of intermediate-, deep- and bottom-water formation, like the Southern Ocean, the model deviates systematically from the "summer" data and simulates values closer to annual averages (in the model this is necessary to represent correctly the

Fig. 8. Distribution of the ratio of model POC export fluxes and satellite-derived primary productivity $(f$-ratio $)$ in the Southern Ocean for (a) annual productivity field of Behrenfeld and Falkowski (1997) (Fig. 9A), (b) annual productivity field of Behrenfeld and Falkowski (1997) (Fig. 9B), and (c) productivity estimates using the VGPM model of Behrenfeld and Falkowski (1997) with the SeaWiFS data from September 1998 to August 1999 (M. Behrenfeld, pers. comm.). 
(a)

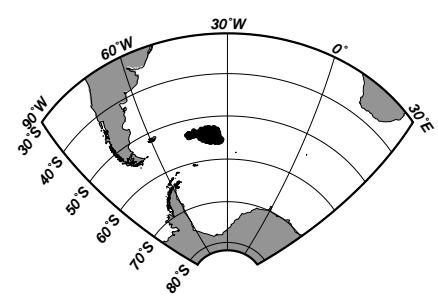

(b)

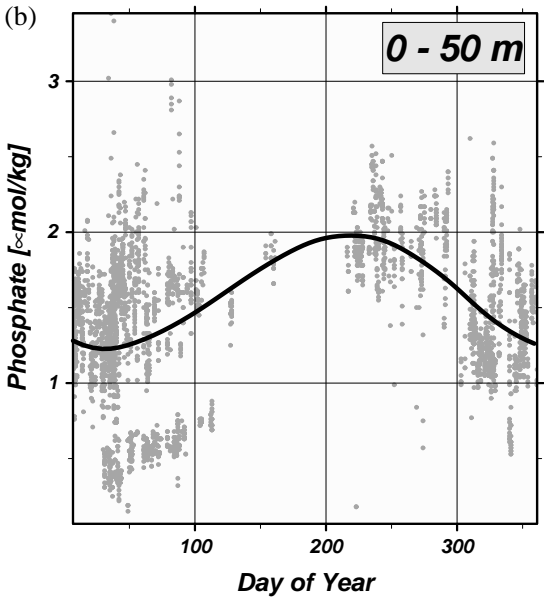

(c)

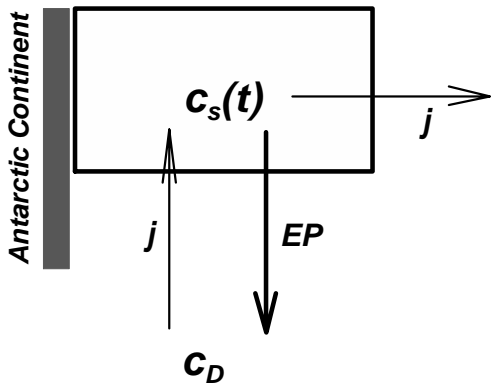

Fig. 9. Seasonal variation of surface-water $(0-50 \mathrm{~m})$ phosphate concentrations in the South Atlantic near $40^{\circ} \mathrm{W} / 54^{\circ} \mathrm{S}(\mathrm{a}$ and $\mathrm{b})$ and schematic diagram of surface nutrient budgets (c). Plot (b) is based on 738 stations from the World Ocean Database 1998, Version 2 (Conkright et al., 1999).

characteristics of the subducted water masses). Strong seasonal changes in biological activity also are observed in the North Atlantic. If the model systematically overestimated production in those regions, one also would expect large systematic differences with satellite estimates.

This shows that neither the uncertainties in the $f$-ratios nor the lack of temporal resolution in the model can explain the observed discrepancy between model and satellite productivity estimates. Thus, the published estimates of primary production based on surface chlorophyll measurements by satellites appear too low in the Southern Ocean. A possible explanation for such an underestimation of biological activity could be the frequently observed sub-surface chlorophyll patches between 30 and $100 \mathrm{~m}$ depth (U. Bathmann, pers. comm.) that contribute to productivity but are not detectable by satellite sensors that probe only the upper few tens of meters. In the Southern Ocean, the fraction of non-detectable (by satellite sensors), sub-surface chlorophyll compared to the total standing stock is likely to be higher than in other areas of the world ocean because of vertical exchange associated with the widespread formation and subduction of intermediate, deep and bottom waters and the strong vertical mixing due to high wind speeds, resulting in a downward transport of chlorophyll and a lowering of surface concentrations.

In principle, such effects can be taken into account if sufficient in situ chlorophyll and productivity profile measurements were available to calibrate the satellite signals. Presently, however, this is not the case. For instance, from the more than 3300 in situ stations that Behrenfeld and Falkowski (1997) use in their study, only 32 are from the Southern Ocean south of $30^{\circ} \mathrm{S}$ (in contrast to about 2400 stations from the northern hemisphere north of $30^{\circ} \mathrm{N}$ ). This small number of calibration points is clearly insufficient to capture adequately the large spatial and temporal variability of biological production in the Southern Ocean. More direct observations are needed in this region to understand better its present and future roles in the global carbon cycle and to make full use of the satellite data.

\section{Acknowledgements}

I am grateful to M. Behrenfeld for insightful discussions and for providing unpublished SeaWiFS results. I also thank D. Antoine, K. Arrigo, D. Kolber and C. Caverhill for sharing productivity data and for helpful comments. Thanks are due 
to the oceanographic tracer community for producing CFC and C14 datasets of unprecedented quality and extent. R. Weiss and W. Smethie provided unpublished CFC data from the South Atlantic. Constructive criticism by two anonymous reviewers helped to improve the manuscript considerably. This is AWI publication 10138.

\section{References}

Anderson, L.A., Sarmiento, J., 1994. Redfield ratios of remineralization determined by nutrient data analysis. Global Biogeochemical Cycles 8, 65-80.

Anderson, T.R., le B. Williams, P.J., 1999. A one-dimensional model of dissolved organic carbon cycling in the water column incorporating combined biological-photochemical decomposition. Global Biogeochemical Cycles 13, 337-349.

Antoine, D., Andre, J.-M., Morel, A., 1996. Oceanic primary production 2. Estimation at global scale from satellite (coastal zone color scanner) chlorophyll. Global Biogeochemical Cycles 10, 57-69.

Arrigo, K.R., Worthen, D., Schnell, A., Lizotte, M.P., 1998. Primary production in Southern Ocean waters. Journal of Geophysical Research 103, 15,587-15,600.

Behrenfeld, M.J., Falkowski, P.G., 1997. Photosynthetic rates derived from satellite-based chlorophyll concentration. Limnology and Oceanography 42, 1-20.

Behrenfeld, M.J., Kolber, Z.S., 1999. Widespread iron limitation of phytoplankton in the south Pacific Ocean. Science 283, 840-843.

Bishop, J.K.B., 1989. Regional extremes in particular matter composition and flux: effects on the chemistry of the ocean interior. In: Berger, W.H., Smetacek, V.S., Wefer, G. (Eds.), Productivity of the Oceans: Present and Past. Wiley, Chichester, pp. 117-137.

Caldeira, K., Duffy, P.B., 2000. The role of the Southern Ocean in uptake and storage of anthropogenic carbon dioxide. Science 287, 620-622.

Carlson, C.A., Ducklow, H.W., Michaelis, A.F., 1994. Annual flux of dissolved organic carbon from the euphotic zone in the northwestern Sargasso Sea. Nature 371, 405-408.

Codispoti, L.A., Christensen, J.P., 1985. Nitrification, denitrification and nitrous oxide cycling in the eastern tropical south Pacific Ocean. Marine Chemistry 16, 277-300.

Codispoti, L.A., Friederich, G.E., Packard, T.T., Glover, H.E., Kelly, P.J., Spinrad, R.W., Barber, R.T., Elkins, J.W., Ward, B.B., Lipschultz, F., Lostaunau, N., 1986. High nitrite levels off northern Peru: a signal of instability in the marine denitrification rate. Science 233, 1200-1202.

Conkright, M.E., Levitus, S., O'Brien, T., Boyer, T.P., Stephens, C., Johnson, D., Baranova, O., Antonov, J., Gelfeld, R., Rochester, J., Forgy, C., 1999. World ocean database 1998, version 2. Technical Report 14, Ocean
Climate Laboratory, National Oceanographic Data Center, Silver Spring, MD.

de Baar, H.J.W., de Jong, J.T.M., Bakker, D.C.E., Löscher, B.M., Veth, C., Bathmann, U., Smetacek, V., 1995. Importance of iron for plankton blooms and carbon dioxide drawdown in the Southern Ocean. Nature 373, 412-414.

Dutay, J.-C., Bullister, J., Doney, S., Orr, J., Najjar, R., Caldeira, K., Campin, J.-M., Drange, H., Follows, M., Gao, Y., Gruber, N., Hecht, M., Ishida, A., Joos, F., Lindsay, K., Madec, G., Maier-Reimer, E., Marshall, J.C., Matear, R.J., Monfray, P., Plattner, G.-K., Sarmiento, J., Schlitzer, R., Slater, R., Totterdell, I.J., Weirig, M.-F., Yamanaka, Y., Yool, A., 2002. Evaluation of ocean model ventilation with CFC-11: comparison of 13 global ocean models. Ocean Modelling, in press.

Eppley, R.W., 1972. Temperature and phytoplankton growth in the sea. Fisheries Bulletin 70, 1063-1085.

Eppley, R.W., Peterson, B.J., 1979. Particulate organic matter flux and planktonic new production in the deep ocean. Nature 282, 677-680.

Fasham, M.J.R., Ducklow, H.W., McKelvie, S.M., 1990. A nitrogen-based model of plankton dynamics in the oceanic mixed layer. Journal of Marine Research 48, 591-639.

Frost, B., 1991. The role of grazing in nutrient-rich areas of the open sea. Limnology and Oceanography 36, 1616-1630.

Gruber, N., Sarmiento, J.L., 1997. Global patterns of marine nitrogen fixation and denitrification. Global Biogeochemical Cycles 11, 235-266.

Hansell, D.A., Carlson, C.A., 1998. Net community production of dissolved organic carbon. Global Biogeochemical Cycles $12,443-453$.

Heras, M.d.1., Schlitzer, R., 1999. On the importance of intermediate water flows for the global ocean overturning. Journal of Geophysical Research 104, 15,515-15,536.

Hestenes, M.R., 1975. Optimization Theory. Wiley Inc., New York.

Howell, E.A., Doney, S.C., Fine, R.A., Olson, D.B., 1997. Geochemical estimates of denitrification in the Arabian Sea and the Bay of Bengal during WOCE. Geophysical Research Letters 24, 2549-2552.

Kaehler, P., Bjornsen, P.K., Lochte, K., Antia, A., 1997. Dissolved organic matter and its utilization by bacteria during spring in the Southern Ocean. Deep-Sea Research II 44, 341-353.

Key, R.M., Quay, P.D., Jones, G.A., McNichol, A.P., von Reden, K.F., Schneider, R.J., 1996. WOCE AMS radiocarbon i: Pacific ocean results (P6, P16 and P17). Radiocarbon 38 (3), 425-518.

Kirchman, D.L., Suzuki, Y., Garside, C., Ducklow, H.W., 1991. High turnover rates of dissolved organic carbon during a spring phytoplankton bloom. Nature 352, 612-614.

Laws, E.A., Falkowski, P.G.W.O., Ducklow, H., McCarthy, J.J., 2000. Temperature effects on export production in the open ocean. Global Biogeochemical Cycles 14, 1231-1246.

Longhurst, A., Sathyendranath, S., Platt, T., Caverhill, C., 1995. An estimate of global primary production in the ocean 
from satellite radiometer data. Journal of Plankton Research 17, 1245-1271.

Maier-Reimer, E., 1993. Geochemical cycles in an ocean general circulation model. Preindustrial tracer distributions. Global Biogeochemical Cycles 7, 645-677.

Martin, J.H., Fitzwater, S.E., 1992. Dissolved organic carbon in the Atlantic, Southern and Pacific Oceans. Nature 356, 699-700.

Martin, J.H., Knauer, G.A., Karl, D.M., Broenkow, W.W., 1987. VERTEX: carbon cycling in the northeast Pacific. Deep-Sea Research I 34, 267-285.

Ogawa, H., Fukuda, R., Koike, I., 1999. Vertical distributions of dissolved organic carbon and nitrogen in the Southern Ocean. Deep-Sea Research II 46, 1809-1826.

Orsi, A.H., Whitworth III, T., Nowlin, W.D., 1995. On the meridional extent and fronts of the antarctic circumpolar current. Deep-Sea Research I 42, 641-673.

Redfield, A.C., Ketchum, B.H., Richards, F.A., 1963. The influence of organisms on the composition of sea-water. In: Hill, M.N. (Ed.), The Sea, Vol. 2. Interscience, New York, pp. $26-77$.

Sarmiento, J.L., Orr, J.C., 1991. Three-dimensional simulation of the impact of Southern Ocean nutrient depletion on atmospheric $\mathrm{CO}_{2}$ and ocean chemistry. Limnology and Oceanography 36, 1928-1950.

Sarmiento, J., Hughes, T., Stouffer, R.J., Manabe, S., 1998. Simulated response of the ocean carbon cycle to anthropogenic climate warming. Nature 393, 245-249.

Sarmiento, J.L., Monfray, P., Maier-Reimer, E., Aumont, O., Murnane, R., Orr, J., 2000. Sea-air $\mathrm{CO}_{2}$ fluxes and carbon transport: a comparison of three ocean general circulation models. Global Biogeochemical Cycles 14, 1267-1281.

Schlitzer, R., 1989. Modeling the nutrient and carbon cycles of the north Atlantic. 2. New production, particle fluxes, $\mathrm{CO}_{2}$ gas exchange, and the role of organic nutrients. Journal of Geophysical Research 94, 12,781-12,794.

Schlitzer, R., 1993. Determining the mean, large-scale circulation of the Atlantic with the adjoint method. Journal of Physical Oceanography 23, 1935-1952.

Schlitzer, R., 2000a. Applying the adjoint method for global biogeochemical modeling. In: Kasibhatla, P., Heimann, M., Hartley, D., Mahowald, N., Prinn, R., Rayner, P. (Eds.), Inverse Methods in Global Biogeochemical Cycles.
Geophys. Monograph Series, American Geophysical Union, Washington, DC, Vol. 114, pp. 107-124.

Schlitzer, R., 2000b. Electronic atlas of WOCE hydrographic and tracer data now available. Eos Transactions AGU 81 (5), 45.

Schlitzer, R., 2000c. Ocean Data View. http://www.awibremerhaven.de/GEO/ODV.

Sharp, J.H., 1997. Marine dissolved organic carbon: are the older values correct? Marine Chemistry 56, 265-277.

Stuiver, M., Quay, P.D., Östlund, H.G., 1983. Abyssal water carbon-14 distribution and the age of the world oceans. Science 219, 849-851.

Suess, E., 1980. Particulate organic carbon flux in the oceans - surface productivity and oxygen utilization. Nature 288, 260-263.

Takahashi, T., Broecker, W.S., Langer, S., 1985. Redfield ratio based on chemical data from isopycnal surfaces. Journal of Geophysical Research 90, 6907-6924.

Takahashi, T., Wanninkhof, R.H., Feely, R.A., Weiss, R.F., Chipman, D.W., Bates, N., Olafsson, J., Sabine, C., Sutherland, S.C., 1999. Net sea-air $\mathrm{CO}_{2}$ flux over the global oceans: an improved estimate based on the sea-air $\mathrm{pCO}_{2}$ difference. In: Nojiri, Y. (Ed.), Proceedings of the Second International Symposium, $\mathrm{CO}_{2}$ in the Oceans. Center for Global Environmental Research, Tsukuba, Japan, pp. 9-14.

Thacker, W.C., Long, R.B., 1988. Fitting dynamics to data. Journal of Geophysical Research 93, 1227-1240.

Toggweiler, J.R., 1994. The ocean's overturning circulation. Physics Today 47 (11), 45-50.

Warner, M.J., Weiss, R.F., 1992. Chlorofluoromethanes in south Atlantic Antarctic intermediate water. Deep-Sea Research I 39, 2053-2075.

Wiebinga, C.J., de Baar, H.J.W., 1998. Determination of the distribution of dissolved organic carbon in the Indian Sector of the Southern Ocean. Marine Chemistry 61, 185-201.

WOCE Data Products Committee, 2000. Woce Global Data, Version 2.0. Technical Report 171/00, WOCE Intern. Project Office, Southampton, UK.

Yamanaka, Y., Tajika, E., 1996. The role of the vertical fluxes of particulate organic matter and calcite in the oceanic carbon cycle: studies using an ocean biogeochemical general circulation model. Global Biogeochemical Cycles 10, 361-382. 